\title{
The effects of gift vouchers and environmental certificates on the demand for a collective DRT system
}

\author{
Aljoscha Minnich ${ }^{1,3} \cdot$ Holger A. Rau² (Jan Christian Schlüter $3,4,5$
}

Accepted: 21 August 2021 / Published online: 18 September 2021

(c) The Author(s) 2021

\begin{abstract}
This paper analyzes in a large-scale field experiment $(\mathrm{N}=1425)$ whether gift vouchers stimulate the use of a demand responsive transportation (DRT) system. This scenario is compared to a situation where customers receive environmental certificates, which report the saved carbon dioxide as a consequence of the bus ride. In our two treatments, the gift vouchers and the environmental certificates could be gained by reaching to a certain threshold of rides with the DRT service (EcoBus). We find that the demand went up more by gift vouchers $(83 \%)$ compared to certificates $(65 \%)$. The data show that vouchers especially outperform the certificates at the end of the treatment phase.
\end{abstract}

Keywords Demand responsive transport · Field experiment · Incentive effects

JEL Classifications C93 · D12 $\cdot$ D83 - D91

Holger A. Rau

holger.rau@uni-goettingen.de

Aljoscha Minnich

aljoscha.minnich@uni-hamburg.de

Jan Christian Schlüter

jan@schluetergroup.org

1 Center for Earth System Research and Sustainability (CEN), University of Hamburg, Grindelberg 5, 20144 Hamburg, Germany

2 University of Göttingen, Platz der Göttinger Sieben 3, 37073 Göttingen, Germany

3 Next Generation Mobility Group, Department of Dynamics of Complex Fluids, Max Planck Institute for Dynamics and Self-Organization, Am Faßberg 17, 37077 Göttingen, Germany

4 Flexible Transport Systems and Complex Urban Dynamics Research Group, "Friedrich List" Faculty of Transport and Traffic Sciences, Technical University of Dresden, Hettnerstr. 1, 01069 Dresden, Germany

5 Econophysics Lab, Chair for Network Dynamics, Center for Advancing Electronics Dresden (cfaed), Technical University of Dresden, Helmholtzstr. 18, 01069 Dresden, Germany 


\section{Introduction}

Collective demand responsive transportation (DRT) systems represent intermediate forms of public transportation, which identify and combine similar travel routes of customers (Brake et al. 2004; Durand et al. 2018). The pooling of passengers increases the number of travelers per vehicle, which reduces fossil fuels and emissions (see also Jokinen 2016; Santi et al. 2014; Nyga et al. 2020). Therefore, DRT systems have the potential to increase the sustainable development in the transport sector. Moreover, they are also an interesting complement to conventional public transport, which may be of importance in rural areas where these services are lacking (Alonso-González et al. (2017)). In this case, DRT systems can be more cost effective and flexible than standard public transportation. Nevertheless, many DRTs have failed because the operations used were not realistically calculated (Davison et al. 2012) and had problems in the marketing (Enoch et al. 2006). Moreover, behavioral factors may play an important role for people's hesitance to use public transportation in the form of DRTs. Fuji et al. (2001) highlight that frequent car users often develop a habit or routine of using their cars, which complicates the switch to other public transport modes. The findings may explain why the number of car commuters is especially high in rural areas. The high number of commuters may be a reason why the demand for DRTs is low in rural areas.

In this paper, we analyze in a natural field experiment practices to promote the demand for DRT in a rural area. In our study, we offer vouchers for local leisure activities when customers use the DRT service. These small gifts aim at familiarizing customers with the transport mode and increasing the demand for it. We test the effectiveness of the gifts by comparing it to another treatment without equivalent. Here, the bus users receive environmental certificates that document the saved carbon dioxide because of the bus ride. Rewarding people for desirable behavior is motivated by findings of experimental economics, which reports positive effects when people receive incentives. For instance, people increase their gym attendances when paid to do so (Charness and Gneezy 2009). Moreover, evidence shows that people reduce smoking when financially rewarded (e.g., Gneezy et al. 2011). In the transport sector, Fuji and Kitamura (2003) also report positive effects of financial incentives, i.e., gifting free bus tickets convinced many customers to switch to buses.

In a similar vein, small gifts were already successfully used to promote sustainable behavior in an urban context different from DRT. In the project "Bella Mossa" the city of Bologna (Italy) rewarded its citizens with small gifts, such as free beer, ice cream, or cinema tickets, if they refrained from using their cars. In this respect, an app was used, which awarded points to citizens when they used public transport, or when they walked or cycled. Bowden and Hellen (2019) report positive effects of the "Bella Mossa" project, i.e., about half of everyday car users showed some form of sustained commitment and behavioral change. Although, the net effect of the project seems to be positive, it is unclear to what extent the increase in sustainable behavior can be attributed to the gifts or to the pure motivational effects. Further evidence shows that offering incentives via an app may increase the use of bicycle (de Kruijf et al. 2018; Huang et al. 2021; Máca et al. 2020), public transport and walking (Tsirimpa et al. 2019). We refer the reader to Hulkkonen et al. (2020) for an overview on initiatives potentially influencing individual travel behavior.

The current study presents the findings of a field experiment on the effectiveness of gift vouchers, which reward the use of a DRT system. We conducted the natural field experiment in connection with the "EcoBus" project between August 13, 2018, and February 24, 
2019. The EcoBus is a door-to-door DRT system that was installed for a trial period of six months in a rural area in northern Germany called Harz. The system was fully integrated in the public transport. The main aim of the DRT system was to reduce environmental and personal costs in comparison to motorized private transport. Therefore, ride-pooling was applied. The project was initiated by the Max Planck Institute for Dynamics and SelfOrganization in Göttingen (Germany) and regional transportation authorities.

In the experiment, we test the effectiveness of two incentive mechanisms (gift vouchers vs. certificates) to increase the demand for DRT. More precisely, customers are rewarded by stamps when driving with the EcoBus. The stamps can be converted to vouchers when reaching a certain threshold level. Customers can reach different threshold levels, i.e., the "silver bonus" (low level, which is achieved by 10 stamps) and the "gold bonus" (high level, which is achieved by 20 stamps). The gold bonus guarantees vouchers of a higher value. To analyze the importance of gift vouchers, we introduce a "certificates" treatment, which also rewards bus rides with stamps, but the customers do not receive gifts. In this condition customers can convert their stamps to environmental certificates, which report the saved amount of carbon dioxide. In the certificates treatment we apply the same thresholds ("silver bonus" and "gold bonus") as in the gift vouchers treatment. The silver (gold) bonus can be converted to a silver (gold) environmental certificate. Depending on the threshold level the certificates report lower/higher levels of saved carbon dioxide.

Our study contributes to the literature in several ways. We focus on a DRT system and try to demonstrate effective ways to increase the acceptance of this certain mode of transport. We focus on a rural setting, characterized by a very low degree of customers who are familiarized with public transportation. Other differences relate to the design of the treatment conditions, i.e, in Bowden and Hellen (2019) customers compete against each other and receive gifts if they substitute daily car usage with various services (e.g., walking, cycling, bus). In contrast to Bowden and Hellen (2019), we have two clear-cut treatments which differ in the incentives (vouchers vs. environmental certificates without equivalent) and reward customers if they achieve the same performance in each testing condition. We apply a quasi-experimental evaluation in comparison to self-disclosures (e.g., Bowden and Hellen 2019; de Kruijf et al. 2018) or experimental evaluations without pre-treatment data (e.g., Máca et al. 2020; Huang et al. 2021). The framework for testing the effectiveness of gifts is particularly suitable here, as our experiment is conducted in the pilot phase of the bus, where customers could not form good or bad long-term experiences with the service. Another strength of our field experiment is that we focus on a large data set with 1425 observations, which encompasses significantly more participants than in many previous studies of behavioral interventions in the transportation sector (Graham-Rowe et al. 2011; Arnott et al. 2014).

We test our main question by applying a difference-in-differences (DiD) approach. After a trial phase, we implemented either the gift vouchers or the environmental certificates. In the DiD approach we compare the difference in the change of the EcoBus rides between these two treatments. It turns out that the usage of EcoBus rides went up by more in the vouchers treatment $(83 \%)$ compared to the certificates treatment $(65 \%)$. We find evidence that the observed effect is mainly taking place at the end of the treatment phase showing more durable effects of vouchers compared to environmental certificates. We speculate that this may indicate potential frustration, as customers in the environmentally-framed certificates treatment may have grown disappointed when realizing that the pilot would soon stop.

The rest of the paper is organized as follows: In Sect. Study data, the DRT setting and the data is introduced to get an overview of the data collection and the travel mechanisms concerning the EcoBus pilot phase. Section Experimental design deals with the experimental 
design. In Sect. Related literature and research hypothesis, we derive our hypothesis based on the related literature. Section Results presents our results and Sect. Conclusion concludes.

\section{Study data}

This section gives an overview of our field setting and the data used for the analysis. First, the DRT system EcoBus and the corresponding customer data collection are presented. Secondly, the accompanying survey is described. Finally, the characteristics of the region are presented briefly to provide more background information.

\section{The EcoBus pilot project}

The EcoBus is a DRT system that offered door-to-door rides in the region of Oberharz in Germany. ${ }^{1}$ During the first pilot phase there was no incentive scheme implemented, as the aim was to measure customers' general preference for the DRT service. The second trial period took place from August 11, 2018, to February 28, 2019. Customers could book their rides via telephone, phone app or website. The maximum number of bookable seats was eight, due to the capacity of each bus. It was possible to use the EcoBus at the same price levels as the local transport, and the different types of tickets were available on the bus itself or at booking offices. The operating time was from 6 a.m. to 10 p.m. on weekdays, with modified times during the weekends. ${ }^{2}$ The goal of the EcoBus project was to analyze the demand of a DRT service for people in rural areas. The project tested their acceptance of this new type of transport as an alternative to private cars, since mobility in rural areas typically depends on private cars. The project was initiated by the Max Planck Institute for Dynamics and Self-Organization in cooperation with the local public transport associations Regionalverband Großraum Braunschweig. It was financially supported by the Südniedersachsenprogramm and the European Regional Development Fund. The EcoBus project was one of the largest field studies of the Max Planck Society to investigate transport solutions in low-demand regions, such as the Oberharz region in Germany. The background was that such regions are rarely considered in studies of new mobility systems. A detailed spatial and temporal analysis of this fully flexible and door-to-door DRT experiment and the study region was carried out in Sörensen et al. (2021).

The data encompass recordings from the EcoBus customer accounts. Every booking request was registered in the middleware of the project. Since customers using a traditional telephone could not be allocated to an account, only the travel patterns of passengers using the website, Android- or iOS applications could be observed. All successful bookings were aggregated on a weekly basis for every customer account. Besides, the registration date and information about the number of additional persons on the bus during a ride, the driving and waiting time, and the number of cancellations were compiled per week. This was

\footnotetext{
1 The service area of the second pilot project can be found in Appendix 1. It can be divided into two parts, namely a full-service area in the major part of the service area and a booking-constraint area in the north. The goal is there is no competition with the local transport in the rather urban area.

2 On Fridays the bus ran between 6 a.m. and 2 a.m. of the next day. On Saturday it ran between 8 a.m. and 2 a.m. of the next day. On Sunday the service ran from 8 a.m. to 10 p.m.
} 
divided by the weekly bookings based on the data collection of the middleware. All in all, 38,472 successful bookings were processed. The bookings referred to the transportation of 51,678 passengers. ${ }^{3}$ During the time of the experiment, there was a change concerning the lead time of the EcoBus booking. This might have led to small changes in travel behavior. In the beginning, it was possible to book journeys in advance on the same day. However, from December 10, 2018, the lead time was reduced to booking an hour in advance of the time of departure. For example, before the change, it was possible to make a booking at 8 a.m. for a trip at 5 p.m. After the change, the pre-order for the trip at 5 p.m. could only be done starting from 4 p.m. In our analyses we also apply robustness checks in the form of DiD regressions with 27 time dummies, which account for the possible effects of this change.

\section{The region}

The service area is located in the "Oberharz region" of the German federate state Lower Saxony (see Percy 1872, p. 248). The main share of the state can be characterized as a rural area (see Federal Institute for Research on Building, Urban Affairs and Spatial Development, 2017). Apart from four larger towns (Goslar, Langelsheim, Clausthal-Zellerfeld and Osterode), the rural structures also apply to the service area.

In the service area, there are approximately 82,000 inhabitants. ${ }^{4}$ As the region has a hilly landscape, it serves as a tourism area during the whole year (see State Office for Statistics Lower Saxony, 2019b). Furthermore, it is a former mining area, which is located next to the bygone border between East and West Germany. The population trend and the forecasts of the region outline that the population is aging and declining (see State Office for Statistics Lower Saxony, 2019a). The average disposable per capita income per year is 20,269 in Goslar and is thus lower than the average in the state of Lower Saxony $(21,045)$ and Germany $(21,952)$ (see Baumann and Seils (2019)). The public transport supply in the Oberharz is not highly developed, especially outside of school hours. ${ }^{5}$ Due to the hilly landscape, the inflexible and time-consuming public transport, besides using private cars there is no real means of transport. The region is connected to the rail network via four towns: Goslar, Langelsheim, Oker and Osterode. These serve as transfer points from rail to bus transport. Mobility by rail within the pilot area is only possible along the border lines but not in the central area. Accordingly, public transport in the central area is strongly characterized by bus lines that connect to the railway hubs. Overall, a total of 23 bus lines operate in the project region, most of which operate in the Goslar and Clausthal Zellerfeld (CLZ) area. In 2018, there were 137 bus stops in Goslar, 43 in CLZ and 63 in Osterode (INKAR 2019). Focusing on these stops, 8793 departures were made in Goslar, 1237 in CLZ and 1246 in Osterode in 2018. Accordingly, the regional center Goslar is the busiest hub. Local service restrictions were used for the EcoBus to avoid jeopardizing the existing public transport and to avoid overloading the DRT system. The population densities of the three towns are 311 inhabitants per square kilometer for Goslar, 356 for CLZ, and 212 for Osterode. The central bus route between Goslar and CLZ runs between 7:00 am and 8:00 pm at 30-minutes intervals. While the accessibility of bus stops hardly seems to be an

\footnotetext{
${ }^{3}$ However, the total demand could not be met, due to a mostly busy system, resulting from the large operating area and a rather inflexible route plan of the algorithm.

${ }^{4}$ Derived by own calculations based on the local authority Braunlage 2018, local authority Goslar 2017, and the local authority Osterode 2012.

${ }^{5}$ Own assessment based on local transport authority RBB n.y., local transport authority VSN n.y.
} 
obstacle, the low frequency of buses makes mobility by public transport in the region difficult (Pütz and Schönfelder 2018). Importantly, the travel times by public transport in the pilot region are generally significantly longer than by private car. Therefore, private cars are the main mode of transport in the region despite the relatively high number of lines. Thus, the EcoBus is an appropriate service to test whether DRT can support the existing public transport structure to increase the flexibility and operating hours (see also Berg and Ihlström 2019).

\section{Survey data}

An accompanying survey was conducted before we introduced the gift vouchers and environmental certificates. The aim of the survey was to learn about customers' perception and motivation to use the EcoBus. The data of this survey is also reported in another study (Nyga et al. 2020), which analyzed the effects of susceptibility, eco-friendliness and dependence on the consumer's willingness-to-pay for the EcoBus. The survey was implemented between October 10 and November 18, 2018. It focused on travel behavior, personal environment, motivation, and demographic information of the participants (see Appendix 2 for further details). Overall, 194 questionnaires were filled out properly. The questionnaire included a maximum of 38 questions with an estimated completion time of 10 minutes. It was possible to access the questionnaire via a notification on the EcoBus website or mobile application, where either a mobile or web version was displayed. All EcoBus users had access to it. Five Amazon vouchers with a value of 10 Euros were used as a possible reward for participation. It was possible to state the email address at the end of the survey to participate in the lottery and to get information about the survey results. We implemented the treatment phase (on the introduction of voucher and certificate incentives in the EcoBus service) one day after the last processing of the questionnaire.

\section{Experimental design}

Our field experiment is designed to test practices, which aim to increase the demand for DRT in rural ares. That is, we analyze the effect of gift vouchers vs. environmental certificates on the demand for EcoBus rides. This section provides information about the incentive types used, the temporal and spatial implementation of the experiment, and the treatments.

\section{Types of incentives}

We implement the gifts in the form of vouchers for offers of local leisure activities, whereas we apply environmental certificates as certificates treatment where customers receive incentives without equivalent. In this respect, we learn whether vouchers with a monetary value are more effective than the potential motivational effect of collecting stamps. The incentive schemes are randomly assigned to customer accounts, based on their postcode (Appendix 3.1 shows examples of the implementation). In the app, subjects received a notification about the beginning of the bonus program and when they managed to reach the thresholds. In addition, the news section of the app included information about the 
implementation of the bonus program. This happened on November 19, 2018, i.e., one day after the last day of the survey (November 18, 2018).

The general structure to gain vouchers and certificates is the same in both treatments. It works as follows. When customers complete an EcoBus booking, the system allocates a virtual collective stamp to the customer account. Customers receive a collective stamp for each ride. Once they reach a certain threshold of collective stamps, they qualify for a bonus level. The lower level ("silver bonus") is reached after they achieve 10 collective stamps, whereas the higher level ("gold bonus") is awarded to users after they collect 20 stamps. Subjects were informed by the app that this only worked if they booked via the website or phone app. Moreover, they were informed that only bookings in the period between November 19, 2018, and February 28, 2019 (our treatment period), would be considered. The EcoBus website and the app included a menu item called "bonus program." The main menu of the bonus program displayed the number of collective stamps of the customers, an overview of the incentives (gift vouchers or environmental certificates), and the possibility to request that the incentive would be sent to the connected mail account. Furthermore, customers were told that the bonus could only be requested as long as the incentives were available in order to address possible supply shortages of the incentives in advance. The customers received a notification at the beginning of the bonus program and when they managed to reach the thresholds. In addition, the news section of the EcoBus included information about the implementation of the bonus program. The news informed customers that there was a silver and gold bonus available, which could be received by collecting stamps. Moreover, they were informed that this new bonus program could be found in the individual applications.

In the vouchers treatment, subjects could exchange their collective stamps for vouchers. More precisely, they could choose between three vouchers from recreational facilities with different offerings for the silver and golden bonus levels. The cooperation partners were located in the service area of the EcoBus. The company "GlowGolf Harz" offered a voucher for anaglyph 3D glasses in exchange for the silver bonus. The glasses could be used with their offer of a special minigolf game. For the gold bonus they offered a free game for a second person who accompanied the customer. The number of their vouchers was unlimited and they were valid until the end of the year 2019. "ErlebnisBocksBerg" offered either a round trip via a gondola for the silver level or a round trip and a coffee and pie menu for the golden level. The same conditions for availability and duration of the voucher program applied. "Aloha Aqualand" offered for a silver bonus access to a sauna and a swimming area for two hours. Whereas, the access was granted for a whole day when customers exchanged a gold bonus. Both bonus levels were only valid for the second person if the first person was a regular paying customer. "Aloha Aqualand" provided 500 vouchers in total, and the validity ended on September 30, $2019 .{ }^{6}$

In the certificates treatment, we used an environmental certificate without equivalent. The certificate informed customers on the amount of saved $\mathrm{CO}_{2}$ with a ride-pooling factor of 1.56 persons on average, in comparison to the usage of a car. The document included an environmental design, which displayed either a silver or a golden coin to reflect the bonus level. Importantly, as mentioned above, we kept constant the general incentive structure. That is, in the certificates treatment customers knew that they would be awarded collective

\footnotetext{
6 We are aware of the fact that the three vouchers may not be perfectly comparable. However, this should not affect the results of the comparison of vouchers vs. certificates, as subjects in the vouchers treatment could choose between the three types of vouchers.
} 


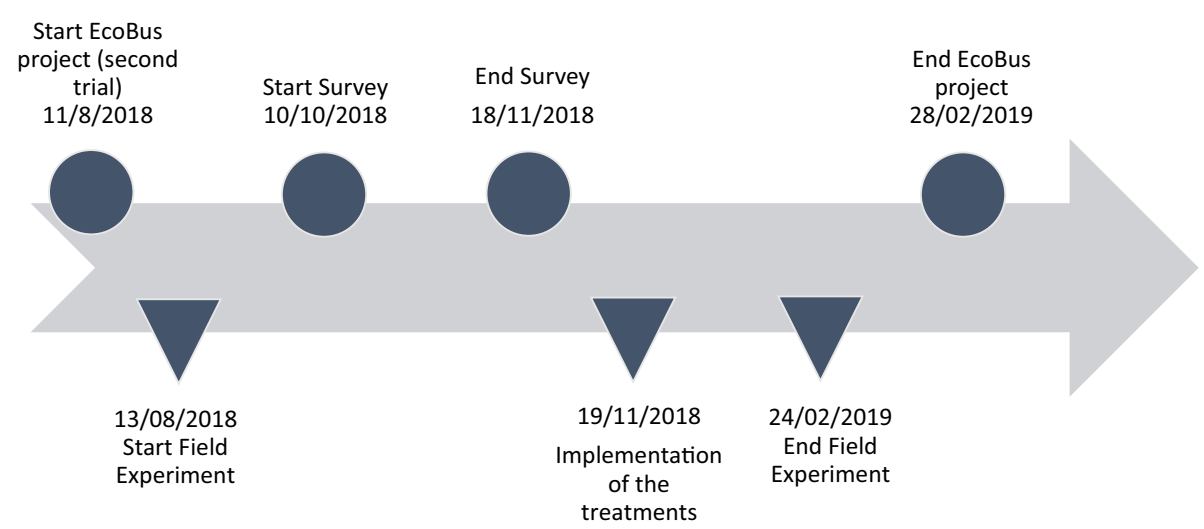

Fig. 1 Time overview of the EcoBus project, the field experiment and the online survey

stamps for each EcoBus ride. They also knew that they could achieve a silver bonus level (when 10 collective stamps were achieved), or a golden bonus level (when 20 collective stamps were achieved). In the certificates treatment they were told that they could exchange the stamps for "silver environmental certificates" or "gold environmental certificates," if they reached the corresponding threshold. On the certificates of the silver and the gold levels, we depicted either 10 or 20 coins on the letterhead. Moreover, the certificates gave information on the amount of saved $\mathrm{CO}_{2}$ for the two threshold levels respectively. There was no limit to the supply of certificates, since they were distributed online. When we refer to the available and requested incentives of subjects with a silver bonus (descriptive analysis in Sect. 5.1), we count subjects who only reached the silver bonus threshold, as well as subjects who reached the gold bonus threshold. Indeed, the gold-bonus subjects may have requested no incentive, or only the silver level, or both the silver and gold level. Therefore, it seems interesting to us to look at how many incentives were available in total for both threshold levels. Moreover, we analyze how many of them were requested. Appendix 3.2 gives an overview of the incentives, the validity, and the supply of the different schemes.

\section{Temporal and spatial implementation of incentives}

In all treatments, the travel pattern was initially observed for 14 weeks without any intervention. Afterward, the incentive scheme was introduced for another 14 weeks (see also Fig. 1 for a chronological overview of the project). The first two and the last four days were not taken into account in the analysis due to an incomplete week in each case. Figure 1 presents an overview of the timing of the study.

The spatial implementation was designed in such a way that it was unlikely that people could find out that there existed different incentive types. To ensure this, we provided people of the same postcode with the same treatment. Therefore, EcoBus customers were asked to declare their corresponding postcode voluntarily in the registration process of the website or app account. To minimize selection effects, the objective was to achieve an equal distribution of accounts for the incentive types so that the full service and the 
booking constraint area were equally distributed as well (see Appendix 3.3 ). ${ }^{7}$ Each group of postcodes was randomly assigned to an incentive scheme. Although, people in different treatments may theoretically know each other, we believe that this should happen very rarely, since the randomization of treatments by postcodes counteracts this problem.

In addition, incentives should also be distributed to EcoBus customers who have not voluntarily provided their postcode. In that case, the postcode of the starting point of the first ride in the treatment phase was used to allocate the incentives. They were then asked to $\log$ in again to the system. If they failed to do so, the system allocated by default no incentives to them.

The distribution of customers across the various postcodes (Appendix 3.3) makes it clear that there are particularly many customers in the middle of the service area who have indicated the postcode of Clausthal. Therefore, we wanted to have all treatments ran in Clausthal because this region is large and attractive. The idea was that the region in Clausthal should be divided again into both types of incentives. To ensure this with our system, these customers had to re-login. However, due to a technical error, the customers of the Clausthal region only received voucher incentives. Doing a re-login was necessary when customers gave a Clausthal postcode. If these subjects did not re-login, the system allocated by default no incentives to them. For this reason we have a gap in the number of observed accounts between the certificates treatment (413) and the vouchers treatment (1012). The overview of the distribution of the accounts to the different treatments and the corresponding postcodes can be found in Table 1. Overall, the randomization of treatments over the postcodes was successful. ${ }^{8}$

\section{Related literature and research hypothesis}

In this paper, we use our app to test the effectiveness of vouchers and environmental certificates to increase the acceptance and demand for a DRT service. We expect that rewarding bus rides with vouchers will have a positive effect on the demand of our DRT service (EcoBus) in the rural area. This is motivated by the positive evidence of financial incentives to guide subjects for a more desirable behavior. For instance, Charness and Gneezy

\footnotetext{
7 The service area was divided into two areas with different booking rules, as shown in Appendix 1 (light green and dark green) and Fig. 6b (light and dark blue) in the Appendix, respectively. The EcoBus project management wanted to make sure that there would be no competition for the local bus company in the light green area, since the local bus company maintains a good service there. In order to avoid the competition for the local bus company, customers with a starting point of the EcoBus in the light green area could not end their trip in the light green area, but only in the dark green area. This was done in order to avoid the same route coverage of EcoBus and the local bus company. In the dark green part of the service area, there were no booking restrictions and customers were free to choose the starting and ending point of their EcoBus trip. The postcodes do not overlap exactly with the two different service areas, but hopefully the figures in Appendix 1 and Appendix 3.3 provide enough reference points to get an idea of the relationship of the postcodes and the service areas.

8 There are two postcodes with a low number of accounts $(37412,38667)$, four with few accounts (37444, $38642,38644,38709)$ and four with many accounts $(37520,38640,38685,38707)$, evenly distributed between the two treatments. In addition, there are the accounts with postcodes outside the treatment area and of course the non-randomized accounts with the Clausthal postcode. In particular, a distinction of the vouchers treatment is made in the analyses in chapter 5, i.e., once all accounts of the vouchers treatment will be used as treatment and once all accounts of the vouchers treatment without Clausthal. The accounts with a postcode outside the service area are also removed from the sample for the robustness checks.
} 


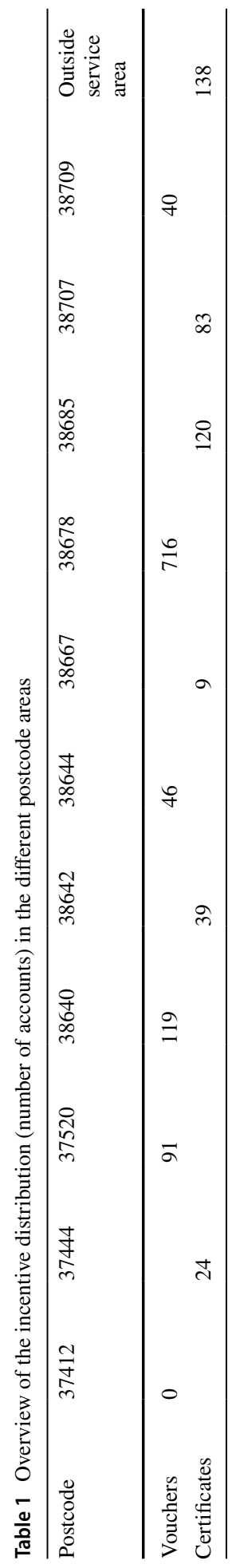


(2009) show that people increase their gym attendances when paid for it. Similar effects are reported in the field of transport, where several studies find that subjects increased the usage of public transportation after they received free tickets (Hunecke et al. 2001; Fujii and Kitamura 2003; Bamberg 2006; Thøgersen and Møller 2008). Furthermore, an extensive literature emphasizes the positive effects of gifts to motivate people without mentioning prices (Heyman and Ariely 2004; Falk 2007; Maréchal and Thöni 2018). Gift cards or vouchers are other examples which can have a positive impact when used as incentives (Lacetera and Macis 2010; Bareket-Bojmel et al. 2017; Lacetera et al. 2012).

By contrast, in our second treatment, customers receive environmental certificates, reporting the saved amount of carbon dioxide. Since, these certificates have no equivalent, we expect that this incentive will be less effective than gift vouchers. Nevertheless, these incentives may have positive effects on the demand for the bus rides. The reason is that non-price information strategies can help to motivate conservation behavior. In the field of organizational economics, it was also shown that non-financial incentives in the form of symbolic rewards have a positive effect on the performance of workers (Kosfeld and Neckermann 2011). In studies on private energy consumption Allcott and Rogers (2014) and Asensio and Delmas (2015) find that informing households with non-price information strategies helps to reduce energy consumption. Similar evidence is found in the field of transport (Graham et al. 2011).

When comparing the two incentive types there is evidence that financial incentives have proven to be more durable than non-price information strategies without equivalent (Ito et al. 2018; Masclet et al. 2003; see also Dolan and Metcalfe 2015; Lefebvre and Stenger 2020). Thus, it is conceivable that customers will have a higher motivation to reach the thresholds of the vouchers as compared to the certificates treatment at the end of the pilot phase. Therefore, we expect that vouchers are more effective than non-financial incentives. This derives our research hypothesis.

Hypothesis The gift vouchers have a stronger effect on the demand for the EcoBus than the environmental certificates.

\section{Results}

Our analysis of the EcoBus rides encompasses all accounts which completed at least one ride and where we have information on the corresponding postcode. One account is not considered because the incentive type was wrongly allocated. Overall, the data consist of 1012 accounts with voucher incentives and 413 accounts with certificate incentives.

Section Travel pattern gives a short overview of the travel behavior of EcoBus customers. Afterward, we present our main results in Sect. Vouchers vs. certificates, which focuses on Difference-in-Differences (DiD) analyses to test our research hypothesis. In Sect. Robustness checks we conclude the results section with robustness checks. Section Survey analysis: travel pattern and purpose of use offers some descriptive insights on the travel behavior of EcoBus users that emerge from the survey.

\section{Travel pattern}

We first overview the travel pattern before and after the implementation of the treatments (see Table 2). To compare the effect of vouchers to the certificate group, we look at the 
Table 2 The number of accounts, the average number of completed EcoBus journeys in the pre-treatment and treatment, and the number of available and requested bonuses of the different treatment groups

\begin{tabular}{llll}
\hline Treatment group & Certificate & Voucher & $\begin{array}{l}\text { Voucher } \\
\text { (without } \\
\text { Clausthal) }\end{array}$ \\
\hline $\begin{array}{l}\text { Average completed EcoBus journeys } \\
\text { (Pre-treatment: 14 weeks) }\end{array}$ & 4.58 & 5.80 & 4.32 \\
$\begin{array}{l}\text { Average completed EcoBus journeys } \\
\text { (Treatment: 14 weeks) }\end{array}$ & 7.58 & 10.62 & 7.93 \\
Available silver bonuses & & & \\
Requested silver bonuses & 86 & 300 & 86 \\
Available golden bonuses & 39 & 81 & 31 \\
Requested golden bonuses & 43 & 166 & 32 \\
Number of accounts & 19 & 42 & 11 \\
Number of observations (28 weeks) & 413 & 1012 & 296 \\
\hline
\end{tabular}

travel behavior for the 14 weeks in the pre-treatment phase and in the treatment phase. We separate the voucher group into all observations and observations without Clausthal. ${ }^{9}$

It can be seen that the voucher group shows the highest increase in average EcoBus journeys in the two phases (from 5.80 to 10.62). It turns out that the average journeys increase $(83 \%)$ is higher than in the certificates treatment, where journeys increase from 4.58 to $7.58(65 \%)$. One may argue that the difference in the increase may be driven by the different initial average numbers of journeys in the pre-treatment phase of the vouchers (5.80) and certificates (4.58) treatments due to potentially different pre-treatment trends. In this respect, it is possible that the voucher sample performs better, as it includes Clausthal, which is more attractive. However, the third column of Table 2 emphasizes that we observe a similar increase of $83 \%$ in the voucher treatment when excluding Clausthal. Thus, we summarize that vouchers yield a clearly higher increase in rides than certificates.

Finally, we take into consideration the odds that arise when the requested bonuses are set in proportion to the available bonuses. Compared to the vouchers, the probability of a requested incentive is higher for certificates. Nevertheless, we find evidence that the vouchers outperform the certificates. An explanation may be that the two incentive types may attract different kinds of people. We speculate that gift vouchers may be effective for extrinsically motivated people, whereas environmental certificates may be particularly effective when people are motivated by reputation-seeking behavior (Bénabou and Tirole 2006). The latter group may have a higher motivation to redeem the bonuses, as in this case they receive a written confirmation on their good deeds in terms of abated carbon dioxide.

To get a first idea of the different effects of vouchers and certificates, we conducted a repeated measures ANOVA. Time is used as a within factor (treatment phase, $F=151.45$, $\mathrm{p}<0.05$ ) and treatments are used as a between factor (voucher, $\mathrm{F}=7.09, \mathrm{p}<0.05$ ). We

\footnotetext{
${ }_{9}$ We make this distinction because a technical problem occurred in the postcode area of Clausthal. Both incentives should have been distributed in this area (East and West), but only voucher incentives were distributed (see again Sect. Temporal and spatial implementation of incentives).
} 
find that the combination of both factors shows a significant effect (treatment, $\mathrm{F}=5.59, \mathrm{p}$ $<0.05)$. The results confirm the data observed in Table 2.

To get deeper insights and to test our hypothesis, we apply DiD regressions in thw next subsection.

\section{Vouchers vs. Certificates}

In this section, we apply four OLS regressions to test the effects of introducing gift vouchers or environmental certificates on the demand for EcoBus rides. ${ }^{10}$ Moreover, models (3) and (4) present the results of pseudo treatments to detect a trend starting before the actual treatment. We only consider the 14 weeks before treatment implementation for models (3) and (4) and declare the second half of the pre-treatment phase as the pseudo-treatment phase (weeks 8 to 14). In all regressions we make use of the Difference-in-Differences (DiD) approach. We follow the model specification of Angrist and Pischke (2008, p. 174f):

$$
y_{i s t}=\alpha+\gamma f_{s}+\delta d_{t}+\beta \text { treatment }_{s t}+\lambda X_{i s t}+\epsilon_{i s t}
$$

$i=$ individual EcoBus account

$s=$ postcode area

$t=$ time period

$y=$ number of successful EcoBus bookings per week

$f \in\{0,1\}=0$ if a certificate (as potential reward) was allocated/ 1 if a voucher (as potential reward) was allocated

$d \in\{0,1\}=27$ dummy variables, which equal 1 for the corresponding week number

treatment $\in\{0,1\}=$ a dummy variable, which equals 1 when a voucher reward was applied in the treatment period (weeks 15-28): Average effect

$X_{1}=$ deleted journeys: average number of journeys a customer deleted, divided by rides. Measure is computed on a weekly base. A deleted journey is a journey, which was not made.

$X_{2}=$ travel time: average driving time per ride on a weekly basis (unit: minutes)

$X_{3}=$ waiting time: average waiting time per ride on a weekly basis (unit: minutes)

$X_{4}=$ additional passenger: average number of other passengers per ride on a weekly basis. The number of other passengers is the total number of persons the booking was made for by a customer.

$X_{5} \in\{0,1\}=$ active account: 1 if the EcoBus account was already registered in the corresponding week number of the observation.

The standard errors are clustered on the postcode level, since the incentives are allocated based on the postcode. The temporal and spatial regression coefficients concerning the DiD approach are not displayed for reasons of conciseness. The coefficient of treatment $1-14$ can be interpreted as the interaction term of the treatment group and the treatment period dummy, which measures the average treatment effect in the sample. The results are presented in Table 3. The idea is that model (1) does not use controls, whereas we add controls on travel behavior in model (2). An advantage of DiD estimation is that the omitted

\footnotetext{
${ }^{10}$ For difference-in-differences estimations, OLS or panel fixed effect estimations are commonly used (Lechner et al. 2016). Therefore, we also perform panel fixed effect estimations as a robustness check in Sect. Robustness checks.
} 
Table 3 Difference in Differences Model: Vouchers vs. Certificates - Average effect

\begin{tabular}{|c|c|c|c|c|}
\hline \multirow[t]{3}{*}{ Subset for } & \multicolumn{4}{|c|}{ Dependent variable: weekly EcoBus journey } \\
\hline & (1) & $(2)$ & (3) & (4) \\
\hline & \multicolumn{2}{|c|}{ Main treatment effect } & \multicolumn{2}{|c|}{$\begin{array}{l}\text { Pseudo treatment } \\
\text { effect }\end{array}$} \\
\hline \multirow{2}{*}{$\begin{array}{l}\text { Treatment }_{1-14} / \\
\text { pseudo-treat- } \\
\text { ment }_{1-7}\end{array}$} & $0.0130 *$ & $0.123 * *$ & 0.062 & -0.018 \\
\hline & $(0.066)$ & $(0.051)$ & $(0.064)$ & $(0.051)$ \\
\hline \multirow[t]{2}{*}{ Deleted journeys } & & $0.068 * *$ & & 0.037 \\
\hline & & $(0.027)$ & & $(0.023)$ \\
\hline \multirow[t]{2}{*}{ Travel time } & & $0.054 * * *$ & & $0.063 * * *$ \\
\hline & & $(0.004)$ & & $(0.006)$ \\
\hline \multirow[t]{2}{*}{ Waiting time } & & $0.012 * * *$ & & $0.010 * *$ \\
\hline & & $(0.002)$ & & $(0.004)$ \\
\hline \multirow{2}{*}{$\begin{array}{l}\text { Additional pas- } \\
\text { senger }\end{array}$} & & $0.151 * * *$ & & $0.203 * * *$ \\
\hline & & $(0.054)$ & & $(0.070)$ \\
\hline \multirow[t]{2}{*}{ Active account } & & $0.262 * * *$ & & $0.253 * * *$ \\
\hline & & $(0.023)$ & & $(0.016)$ \\
\hline \multirow[t]{2}{*}{ Constant } & $0.140 *$ & -0.004 & $0.162 * * *$ & -0.016 \\
\hline & $(0.074)$ & $(0.027)$ & $(0.056)$ & $(0.027)$ \\
\hline Observations & 39,900 & 39,900 & 19,950 & 19,950 \\
\hline $\mathrm{R}^{2}$ & 0.018 & 0.348 & 0.012 & 0.367 \\
\hline Adjusted $\mathrm{R}^{2}$ & 0.018 & 0.347 & 0.011 & 0.367 \\
\hline $\begin{array}{l}\text { Residual Std. } \\
\text { Error }\end{array}$ & 1.496 & 1.220 & 1.294 & 1.036 \\
\hline F Statistic & $25.711 * * *$ & $624.865 * * *$ & $16.406 * * *$ & $578.708 * * * *$ \\
\hline
\end{tabular}

$* \mathrm{p}<0.1 ; * * \mathrm{p}<0.05 ; * * * \mathrm{p}<0.01 ;$ Standard errors in parentheses

variable bias is only present for covariates that vary simultaneously on the spatial and time level (Angrist and Pischke 2008, p. 177f). Because of the small time span and regional proximity (we vary treatments at a small regional level), covariates such as gasoline prices, ticket prices, or geographic or demographic variables should not have an effect on treatment estimates. However, it is possible that short-term service inequalities could vary by the flexibility of the EcoBus at a temporal and spatial level, so we control for short-term trip characteristics.

The significant and positive coefficients of treatment $_{1-14}$ demonstrate in regressions (1) and (2) that the EcoBus demand increases significantly stronger when vouchers are introduced, as compared to certificates. The results are robust for including controls. Every control variable has a positive impact and is significant. The positive impact of deleted journeys and waiting time might be explained by the fact that people with a high dependency on regular trips with the EcoBus are more likely to accept a higher waiting time and have more patience while booking. Customers who have a longer travel time use the EcoBus more often. Interestingly, it can also be seen that a social environment has positive effects, 
Table 4 Difference in Differences Model: Vouchers vs. Certificates-Weekly effects

\begin{tabular}{|c|c|c|c|c|}
\hline \multirow{3}{*}{ Subset } & \multicolumn{4}{|c|}{ Dependent variable: weekly EcoBus journeys } \\
\hline & (1) & (2) & (3) & (4) \\
\hline & & & without $\mathrm{Cl}$ & usthal \\
\hline \multirow[t]{2}{*}{ Treatment $_{1}$} & $0.194 * * *$ & 0.101 & 0.095 & -0.0130 .013 \\
\hline & $(0.064)$ & $(0.082)$ & $(0.092)$ & $(0.075)$ \\
\hline \multirow[t]{2}{*}{ Treatment $_{2}$} & 0.123 & 0.015 & -0.002 & -0.022 \\
\hline & $(0.087)$ & $(0.052)$ & $(0.096)$ & $(0.060)$ \\
\hline \multirow[t]{2}{*}{ Treatment $_{3}$} & 0.085 & 0.011 & -0.083 & $-0.123 *$ \\
\hline & $(0.091)$ & $(0.070)$ & $(0.101)$ & $(0.064)$ \\
\hline \multirow[t]{2}{*}{ Treatment $_{4}$} & $0.119 * *$ & 0.061 & -0.023 & -0.084 \\
\hline & $(0.059)$ & $(0.065)$ & $(0.050)$ & $(0.070)$ \\
\hline \multirow[t]{2}{*}{ Treatment $_{5}$} & 0.027 & 0.094 & -0.092 & -0.007 \\
\hline & $(0.093)$ & $(0.078)$ & $(0.089)$ & $(0.087)$ \\
\hline \multirow[t]{2}{*}{ Treatment $_{6}$} & $0.068^{*}$ & $0.080 * * *$ & 0.021 & 0.032 \\
\hline & $(0.038)$ & $(0.030)$ & $(0.075)$ & $(0.043)$ \\
\hline \multirow[t]{2}{*}{ Treatment $_{7}$} & $0.123^{* *}$ & 0.065 & 0.136 & $0.084 *$ \\
\hline & $(0.053)$ & $(0.041)$ & $(0.085)$ & $(0.045)$ \\
\hline \multirow[t]{2}{*}{ Treatment $_{8}$} & 0.121 & $0.122 * *$ & -0.017 & -0.015 \\
\hline & $(0.109)$ & $(0.057)$ & $(0.120)$ & $(0.035)$ \\
\hline \multirow[t]{2}{*}{ Treatment $_{9}$} & 0.122 & 0.120 & 0.054 & 0.005 \\
\hline & $(0.095)$ & $(0.114)$ & $(0.094)$ & $(0.113)$ \\
\hline \multirow[t]{2}{*}{ Treatment $_{10}$} & 0.124 & $0.159 * *$ & 0.032 & 0.085 \\
\hline & $(0.126)$ & $(0.080)$ & $(0.129)$ & $(0.102)$ \\
\hline \multirow[t]{2}{*}{ Treatment $_{11}$} & $0.285^{* * *}$ & $0.309 * * *$ & $0.179 * *$ & $0.194 * *$ \\
\hline & $(0.069)$ & $(0.057)$ & $(0.071)$ & $(0.085)$ \\
\hline \multirow[t]{2}{*}{ Treatment $_{12}$} & $0.182 * *$ & $0.259 * * *$ & 0.107 & $0.177 * *$ \\
\hline & $(0.084)$ & $(0.071)$ & $(0.133)$ & $(0.070)$ \\
\hline \multirow[t]{2}{*}{ Treatment $_{13}$} & $0.112^{*}$ & $0.157^{* * * *}$ & $0.125^{*}$ & $0.137 *$ \\
\hline & $(0.066)$ & $(0.047)$ & $(0.074)$ & $(0.071)$ \\
\hline \multirow[t]{2}{*}{ Treatment $_{14}$} & $0.136^{* *}$ & $0.165^{* * *}$ & 0.067 & $0.082 *$ \\
\hline & $(0.053)$ & $(0.050)$ & $(0.053)$ & $(0.046)$ \\
\hline \multirow[t]{2}{*}{ Deleted journeys } & & $0.068 * *$ & & $0.053 * * *$ \\
\hline & & $(0.027)$ & & $(0.028)$ \\
\hline \multirow[t]{2}{*}{ Travel time } & & $0.054 * * *$ & & $0.053 * * *$ \\
\hline & & $(0.004)$ & & $(0.008)$ \\
\hline \multirow[t]{2}{*}{ Waiting time } & & $0.012 * * *$ & & $0.010 * * *$ \\
\hline & & $(0.002)$ & & $(0.002)$ \\
\hline \multirow[t]{2}{*}{ Additional passenger } & & $0.152 * * *$ & & 0.121 \\
\hline & & $(0.053)$ & & $(0.079)$ \\
\hline \multirow[t]{2}{*}{ Active account } & & $0.265^{* * *}$ & & $0.223 * * *$ \\
\hline & & $(0.023)$ & & $(0.022)$ \\
\hline \multirow[t]{2}{*}{ Constant } & $0.140^{*}$ & -0.004 & $0.181 * * *$ & 0.012 \\
\hline & $(0.074)$ & $(0.026)$ & $(0.062)$ & $(0.026)$ \\
\hline Observations & 39,900 & 39,900 & 19,852 & 19,852 \\
\hline $\mathrm{R}^{2}$ & 0.019 & 0.348 & 0.014 & 0.400 \\
\hline Adjusted $\mathrm{R}^{2}$ & 0.017 & 0.347 & 0.012 & 0.398 \\
\hline Residual Std. Error & 1.496 & 1.220 & 1.274 & 0.994 \\
\hline F Statistic & $17.900 * * *$ & $452.473 * * *$ & $6.515^{* * *}$ & $280.706^{* * *}$ \\
\hline
\end{tabular}

$* \mathrm{p}<0.1 ; * * \mathrm{p}<0.05 ; * * * \mathrm{p}<0.01 ;$ Standard errors in parentheses 
i.e., the coefficients of additional passenger are positive and significant. ${ }^{11}$ This suggests that people who book in groups more often use the bus. Furthermore, in models (3) and (4) it can be seen that pseudo-treatment ${ }_{1-7}$ is insignificant, which shows that there is no starting trend before the actual treatment. Hence, we are confident that the two treatment groups can be compared, since parallel trends exist. Moreover, it is unlikely that people in these treatment groups differ, as there is a high regional proximity with similar population in our small study area. The regional proximity of the populations is also reflected by the similarity of the postcodes in the two treatment groups (see Table 1). Taken together, models (1) and (2) confirm the previous results, i.e., the vouchers outperform the certificates, which supports our research hypothesis.

\section{Robustness checks}

Next, we provide several robustness checks for our findings. We start with a case study approach of our main analysis.

In Table 4 we present models, where we apply a similar approach as in Table 3 . The main difference is that we apply 14 weekly dummy variables, which equal 1 when a voucher reward was applied in the treatment period (weeks 15-28). In models (1-2) we focus on the full sample, whereas in model (3-4) we exclude the data of Claustahl. The standard errors are clustered on the postcode level, since the incentives are allocated based on the postcode. ${ }^{12}$ The temporal and spatial regression coefficients concerning the DiD approach are not displayed for reasons of conciseness.

The results show in regressions (1) and (2) that all treatment coefficients are positive. Furthermore, the treatment weeks $1,4,6,7,11,12,13$, and 14 are significant in the first regression, the treatment weeks $6,8,10,11,12,13$, and 14 are significant in the second regression. It seems to be the case that the introduction of vouchers as an incentive particularly affects the middle and late periods of the treatment phase (model (2)). Turning to the sample without Clausthal (models (3)-(4)), the results show that the treatment coefficients are initially rather negative and from the middle periods (except for treatment week 8) of the treatment phase onward they change to positive. Furthermore, the treatment weeks 11 and 13 are significant in model (3), whereas the treatment weeks 7, 11, 12, 13, and 14 are significant in model (4) of the second regression. We summarize that the robustness check supports the findings in Table 3, i.e., vouchers outperform certificates, especially at later time periods. Thus, the robustness check adds further support for our main findings.

The results are summarized in Fig. 2, which presents an overview of the regression models on the weekly treatment estimators. Each panel ((a)-(d)) displays the treatment estimators of models (1)-(4) from Table 4 and pseudo-treatment estimators of models (1)-(4) from Table 7 in the Appendix. The OLS estimators from Table 7 in the Appendix are used to test the assumption of common trends at the weekly level. We find a significant effect for week 11 in model (1) and therefore the results from model (1) in Table 4 should be interpreted cautiously due to potential omitted variable bias. We find no evidence of a different common trend between the voucher and certificate treatments when including controls

\footnotetext{
11 Collinearity does not appear to be a problem for the models in Table 3, since the variance inflation factors of all estimators are below 5 .

12 Collinearity does not appear to be a problem for the models in Table 4, since the variance inflation factors of all estimators are at least below 5 .
} 


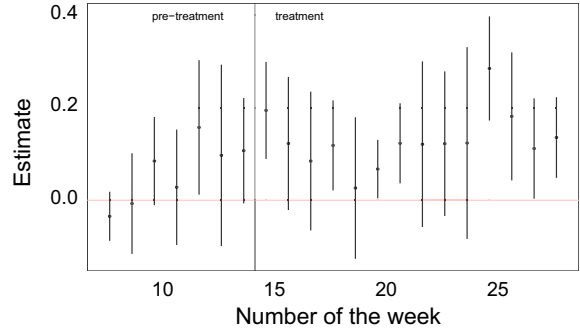

(a) Table 4, column 1: Basic model

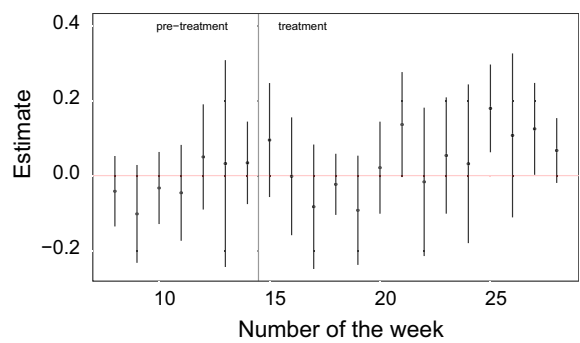

(c) Table 4, column 3: Without Clausthal

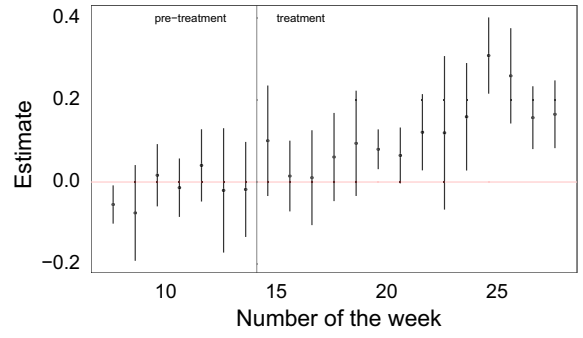

(b) Table 4, column 2: Basic model including control variables

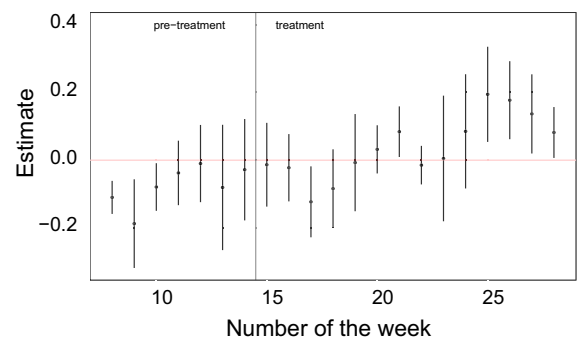

(d) Table 4, column 4: Without Clausthal including control variables

Fig. 2 The weekly treatment estimators quantifying the difference between vouchers and certificates before the treatment phase (stemming from Table 7 in Appendix 4) and within the treatment phase (stemming from Table 4) with a $90 \%$ confidence interval

(model 2). The only significant treatment dummy is negative, which suggests that in these weeks the voucher group demanded fewer EcoBus rides than the certificate group. A finding which would rather attenuate a possible significant effect of voucher incentives for the EcoBus demand. We do the same common trend assumption testing for the vouchers treatment without Clausthal vs. the certificate incentives. An OLS regression (see columns (3) and (4) in Table 7 in the Appendix) emphasizes that no different trend occurs between the two treatments (model 3). We find that the seven treatment dummies are insignificant. The exception are treatment dummies 1,2 and 3 in model 4, which are negative and significant, i.e., in the middle periods of the pre-treatment phase there is a slightly higher demand in the certificate incentives treatment when using the control variables. This is again an effect that rather attenuates a possible positive effect of the vouchers. Therefore, we are confident that the two treatment groups can be compared for models (2)-(4) in Table 4, although the results in model (1) should be interpreted cautiously. It can be clearly seen in Fig. 2 that the vouchers outperform the certificates over time.

Next, we conduct a robustness check, where we apply additional model variations of the regressions in Table 4. In this case, we use a panel fixed effect model instead of the OLS models. The panel fixed effect model is fixed for the week number and the individual customer. The results are shown in Table 8 in the Appendix. Overall, the results are very similar, which is not surprising since the basic Difference in Differences model can also be seen as a kind of panel fixed effects regression where the fixed effect level is the treatment 
allocation variable $f_{s}$ (voucher) instead of the individual customers. It should also be mentioned that in regression (3) of Table 8 only treatment period 11 is significant.

Final robustness checks concentrate on the randomization procedure, i.e., we test whether customers who live in the limited service area, outside the service area or who did not report their postcode may have biased the findings. Here, we analyze whether treatment differences between voucher and certificate incentives hold when we exclude the corresponding samples separately. We apply the three different sample changes to the regressions from Table 4. In this regard, we removed the EcoBus accounts from outside the service area, from the limited service area and we excluded the accounts with estimated postcodes. Overall, the results of the six regressions are quite similar as the results from Table 4. The robustness checks add further support for our findings in Table 4.

The data suggest that incentives influence the demand for the DRT, which is also mirrored in the development of aggregated customers' telephone bookings over time. Here, we find a clear decline after the treatment phase started and several app users were offered the incentives (see Figure 8 in the Appendix). We speculate that customers substituted the telephone bookings with internet bookings in order to receive the incentives. ${ }^{13}$

\section{Survey analysis: Travel pattern and purpose of use}

The survey reveals that the participants complete 11.91 rides per week, on average, for all different kinds of transport modes. ${ }^{14}$ A round trip counts as two completed rides. 45.88 $\%$ of the survey participants use mainly single tickets, and $23.20 \%$ use multiple discount tickets (for 2, 4, 8 or 10 rides). The others use daily, monthly or other types of subscription models. The participants were also asked what transport modes they have access to and what transport modes they regularly use. Multiple answers were possible. The bus and EcoBus show a very similar pattern in terms of their high availability and high regular usage. Another conspicuous finding is subjects' high regular car usage. This supports the notion that people living in a rural area depend on their own car, as they have poor access to public transportation. This is also supported by the high demand for the EcoBus, reflected by the high number subjects' regular usage. The majority of the participants state in the survey that they have a bad perception of the local transport system. This is in line with the idea that frequent car users may develop a habit using their cars, since they have a bad perception of the public transportation (Fuji et al. 2001).

In terms of the EcoBus usage, we find that most of customers use it for recreational activities. Work, shopping, education, doctors visits and other purposes are mentioned as well, but the EcoBus is only moderately chosen for those purposes. Regarding the motivation to use the EcoBus, the following factors play a role. The predominant reason is flexibility. Furthermore, quickness, low costs, and protecting the environment are important

\footnotetext{
13 This would be a success due to the high marginal operating costs of a telephone service.

14 We carefully eliminated double entries concerning the customer ID and entries from participants who declared that it was not possible to fill out the questionnaire. We also did not use questionnaires, which were not completed. Furthermore, one data set was not used because of using the proposed minimum value of the customer ID. The survey tool suggested a minimum value after the person had not entered anything in the question about the EcoBus customer ID.
} 
factors followed by curiosity, no alternative, and others (an overview of customers' answers is reported in Figure 8 of the Appendix).

\section{Conclusion}

This paper investigated the effects of gift vouchers to stimulate the demand for DRT in a rural area. We compared this scenario to a situation where bus rides were rewarded with environmental incentives without equivalent. The results show that gift vouchers may provide important incentives to stimulate the demand for DRT in rural areas. After the introduction of the gift vouchers, we find evidence that the EcoBus rides significantly increased stronger (83\%) than in the certificates treatment (65\%). A closer look shows that vouchers especially outperform the certificates in later time periods. This is in line with results of Ito et al. (2018) and Masclet et al. (2003) on the effectiveness of financial and non-financial incentives in late periods. The treatment difference between the two incentive treatments may also be spurred by the fact that the intrinsic motivation of the customers in the certificates treatment shrinks at the near end of the pilot phase. We speculate that this may be related to some form of disappointment of intrinsically-motivated customers when they realize that a project, which has positive effects on the environment will be stopped soon. At the same time, extrinsically motivated customers may also become disappointed when realizing that they will soon do not receive any gifts. However, they might still be motivated to reach the thresholds by the end of the pilot phase in order to receive a gift.

We acknowledge that our design cannot uncover whether the customers lastingly changed their habits because of our interventions. To control for this, we would have needed a different design, with a EcoBus project, which would have been run for a longer time. Nevertheless, we believe that our findings provide important insights for policymakers, who aim to stimulate the demand for DRT. Our results highlight that it pays off to motivate customers with incentives. In this respect, we outline that vouchers for small gifts are more effective than certificates. It follows that policymakers should partner with local suppliers, which may offer vouchers for the DRT bus service. If these collaborations are established, no or only low costs may arise, since local suppliers may sponsor the gifts, as in our example. If however, policymakers have no access to gift vouchers, or if the costeffectiveness ratio of vouchers is poor, environmental certificates may be an alternative with almost zero cost. Our findings highlight the importance of behavioral factors, which may play a crucial role in customers' motivation to use DRT. This provides an avenue for potential future research. First, it is interesting to explore more deeply the potential underlying channels of subjects' motivation to use alternative public transportation services. In this respect, it would be intriguing to identify more practices, which may help to overcome bad habits. Second, environmental framing may also have a positive effect. In this respect, it would be interesting to further explore other cost-effective solutions, which may exploit the sustainable character of DRT in the marketing of the service.

Acknowledgements We would like to thank the software development team of the Max Planck Institute for Dynamics and Self-Organization for the implementation of this field experiment. In this respect, we especially want to thank the HAWK Göttingen and Fabian Maus for his programming activities. Furthermore, 
we would like to explicitly thank the leisure facilities for the thoughtful, friendly and professional cooperation and for the provision of the vouchers.

Author contributions All authors have contributed equally to the study (design of the experiment, data analyses, writings).

Funding Open Access funding enabled and organized by Projekt DEAL. The EcoBus project itself was financially supported by the Südniedersachsenprogramm and the European Regional Development Fund. The research itself was funded by the Max Planck Society.

Availability of data and material The data sets cannot be made public. The data that have been used is confidential. This is because of data protection concerns, as very personal data such as addresses are part of the travel data sets. Furthermore, it would be possible to combine the travel data with personal data from the questionnaire.

\section{Declarations}

Technical Note The data cleaning, the calculations and the visualizations were carried out with the help of $\mathrm{R}$ and extensions (see R Core Team, 2019). In particular, the R-package stargazer (to visualize the regression tables) and the R-package ggplot2 (to visualize the graphs) are to be mentioned here (see Hvalac, 2018, and Wickham 2016).

Conflict of interest The authors declare that they have no competing interests.

Ethical approval The field experiment was conducted in accordance with the rules of the GLOBE Lab at the University of Göttingen. We have an universal approval for research, which is conducted in line with the GLOBE Lab rules.

Open Access This article is licensed under a Creative Commons Attribution 4.0 International License, which permits use, sharing, adaptation, distribution and reproduction in any medium or format, as long as you give appropriate credit to the original author(s) and the source, provide a link to the Creative Commons licence, and indicate if changes were made. The images or other third party material in this article are included in the article's Creative Commons licence, unless indicated otherwise in a credit line to the material. If material is not included in the article's Creative Commons licence and your intended use is not permitted by statutory regulation or exceeds the permitted use, you will need to obtain permission directly from the copyright holder. To view a copy of this licence, visit http://creativecommons.org/licenses/by/4.0/.

\section{Appendices}

\section{Appendix 1}

Figure 3. 


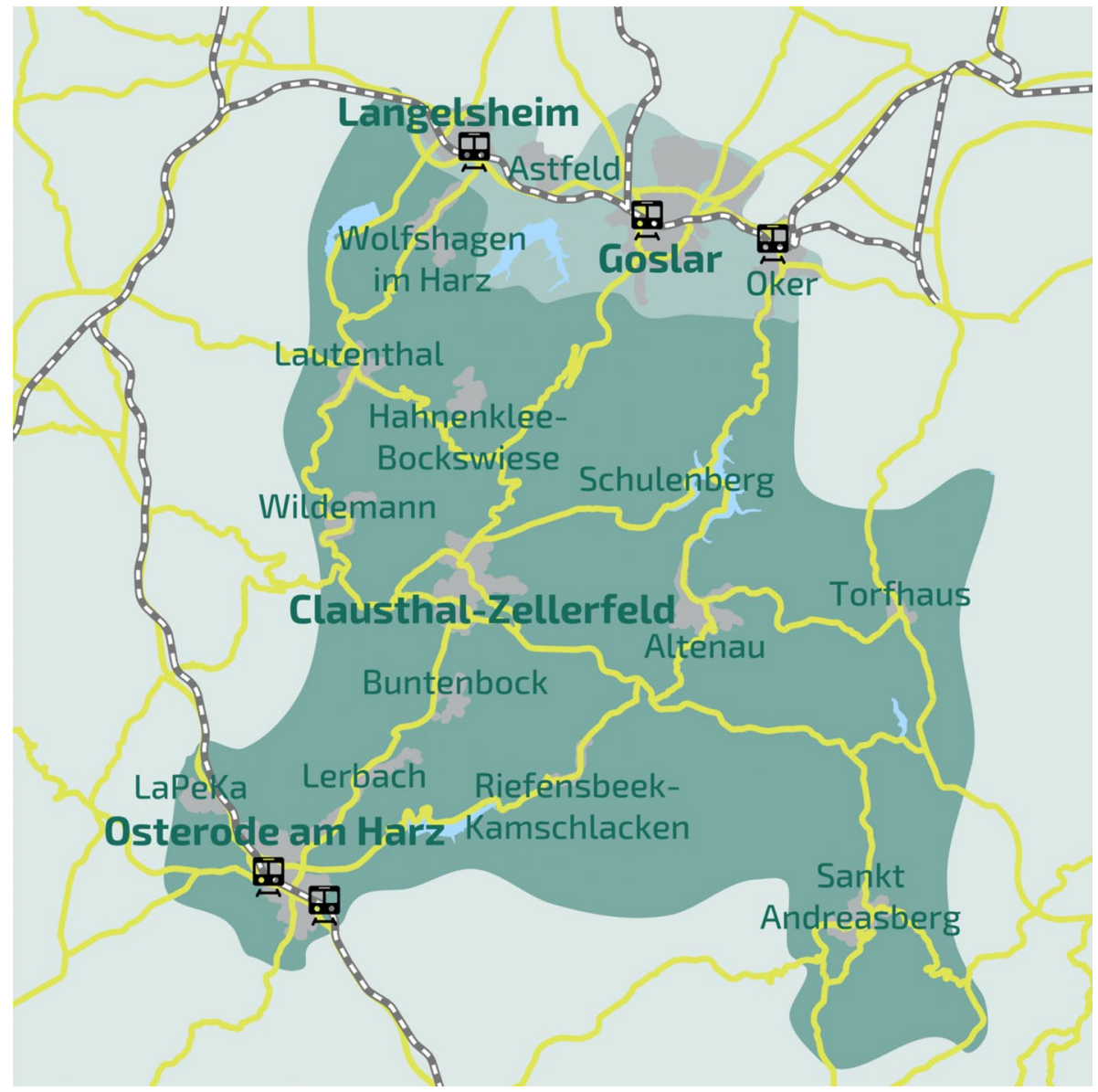

Fig. 3 Service area of the second EcoBus pilot phase: Full service (dark green), booking constraint (light green). Source: EcoBus Team 2018

\section{Appendix 2}

Table 5. 
Table 5 Overview of the variables from the questionnaire

\begin{tabular}{|c|c|}
\hline Travel behavior & Personal environment \\
\hline EN01 EcoBus ticket & UN01 solitarily or not \\
\hline EN02 mobile phone ownership & UN02 number of room mates \\
\hline EN03 quality internet & UN03 EcoBus users (room mates) \\
\hline EN04 public transport supply & UN04 using together EcoBus \\
\hline EN05 average weekly transport use & UN05 number of friends using EcoBus \\
\hline EN06 availability of transport modes & UN06 telling others about EcoBus \\
\hline EN07 usage of transport modes & UN07 reaction \\
\hline \multicolumn{2}{|l|}{ EN08 purpose of EcoBus usage } \\
\hline \multicolumn{2}{|l|}{ EN09 willingness to pay (different modes) } \\
\hline \multicolumn{2}{|l|}{ EN10 appreciation of bus system } \\
\hline \multicolumn{2}{|l|}{ EN11 appreciation EcoBus } \\
\hline \multicolumn{2}{|l|}{ EN12 suggestion for improvement (EcoBus) } \\
\hline Motivation & Demographic information \\
\hline ME01 main reason using EcoBus & DV01 gender \\
\hline ME02 price comparison alternative & DV02 age \\
\hline ME03 travel time comparison & DV03 education \\
\hline ME04 private environment protection & DV04 living environment \\
\hline ME05 importance environment protection & DV05 service area \\
\hline ME06 comparison personal environment & DV06 monthly budget \\
\hline ME07 EcoBus eco-friendly & DV07 political party \\
\hline \multirow[t]{2}{*}{ ME08 knowledge question about pollution } & DV08 voucher/certificate \\
\hline & DV09 constumer ID \\
\hline
\end{tabular}

Others

AA01 seriously answered

AA03 results and lottery

\section{Appendix 3}

\section{Appendix 3.1}

Figures 4 and 5. 


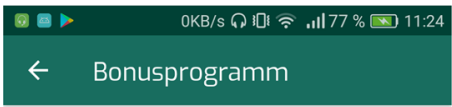

Aktuelle Anzahl an Sammelmarken:

10

Anzahl benötigter Sammelmarken für den silbernen Gutschein: 10

Anzahl benötigter Sammelmarken für den goldenen Gutschein: 20

$$
\begin{aligned}
& \text { (i) Programminfo } \\
& \text { (i) Bonusübersicht }
\end{aligned}
$$

Solange der Vorrat reicht, können Sie sich einen Gutschein von unseren Kooperationspartnern aussuchen, wenn Sie genug Marken dafür gesammelt haben.

$$
\text { BONUS ERHALTEN }
$$

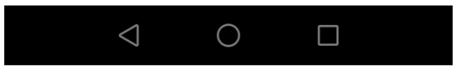

(a) Android main page (voucher incentive)
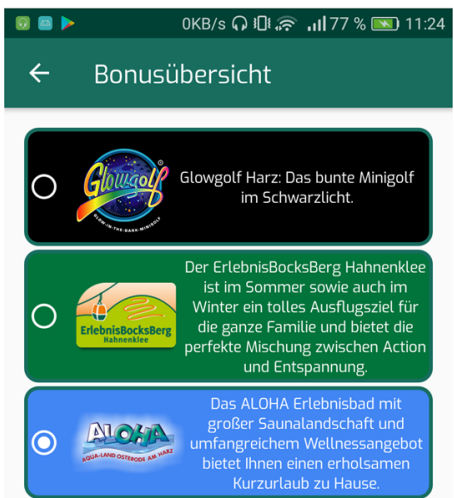

SILBER

GOLD

Der zweite Eintritt ist gratis! Tageseintritt Saunalandschaft inkl. Erlebnisbad für die 2. Person kostenlos. (Eine Person zahlt, die 2. Person hat freien Eintritt.) Gutschein ist gültig bis 30.09.2019.

\section{$\triangleleft$ ○ \\ $\square$}

(c) Android overview of the incentives (voucher incentive)

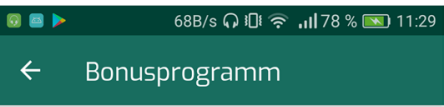

Aktuelle Anzahl an Sammelmarken:

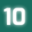

Anzahl benötigter Sammelmarken für die silberne Umwelturkunde: 10

Anzahl benötigter Sammelmarken für die goldene Umwelturkunde: 20

\section{(i) Programminfo \\ (i) Bonusübersicht}

Solange der Vorrat reicht, können Sie eine Umwelturkunde anfordern, wenn Sie genug Marken dafür gesammelt haben

BONUS ERHALTEN $\square$

(b) Android main page (certificate incentive)
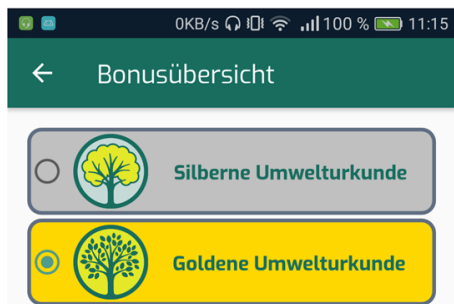

Als Dankeschön für 20 abgeschlossene Fahrten erhalten Sie die goldene Urkunde für Ihr umweltfreundliches Nahverkehrsverhalten.

Fig. 4 Main page of the voucher incentive (a) and the certificate incentive (b) and overview of the incentives (voucher) (c) and overview of the incentives (certificate) (d); exemplary for Android 


\section{EcoBus

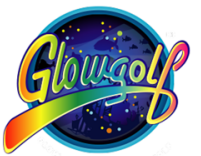

Gutscheincode: GGH1001EB01

Gutschein: 30 Brille fur den besonderen Minigolf-Spielspaß!
Einzulösen bis: 31.12 .19

Der Gutschein ist nur gültig, wenn dieser ausgedruckt oder auf dem Handy vorgelegt wird
Der Gutschein kann nur einmal eingelöst werden.

\section{EcoBus}

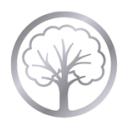

Silberne Umwelturkunde für zehn abgeschlossene Fahrten

Liebe/r EcoBus: Nutzer/in,

vielen Dank, dass Sie sich für ein umweltfreundlicheres Nahwerkelirskonzept entschieden EcoBus fahren. Sie hraben seit der Einfïlurung des Bonusprogramms

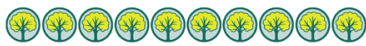

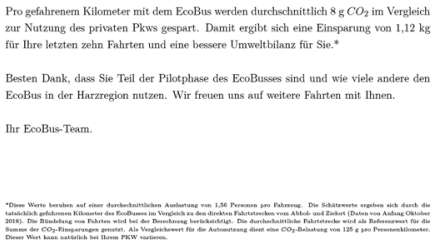

Pro gefahrenem Kilometer mit dem EocBus werden durchschnittlich $8 \mathrm{~g} \mathrm{CO}_{2}$ im Vergleich
zur Nutzung des privaten Pkns gespart. Demit ergibt sich eine Einsparung von $1,12 \mathrm{~kg}$ für Ihre letzten zehn Fahrten und eine bessere Unwweltbilanz für Sie."

Besten Dank, dass Sie Teil der Pilotphase des EcoBusses sind und wie viele andere den.$$
\text { De Der }
$$

Ihr EcoBus-Team

(b) Example of a silver incentive (certificate)

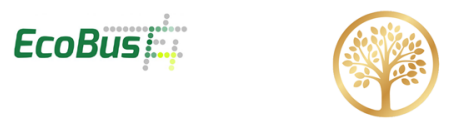

Goldene Umwelturkunde für zwanzig abgeschlossene Fahrten

Liebe/r ExoBus-Nutzer/in.

vielen Dank, dass Sie sich fiur ein umweltifremendlicheres Nahverkehrskonzept entschieden haben und mit dem EooBus fahren. Sic haben seit der Einfïhirung des Bonnsprogramms

Gutscheincode: EBB2508EB02 hereits zwanzig Umweltmarken gesamm

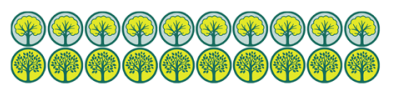

Pro gefalirenem Kiloneter mit dem ExoBus werden durchschnittlich $8 \mathrm{~g} \mathrm{CO}_{2}$ in Vergleich zur Nutzung des privaten Pkns gespart. Damit ergibt sich eine Einsparung von 2,24 kg

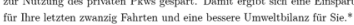

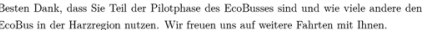
Ihe EcoBus-Team.

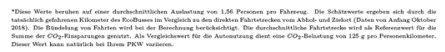

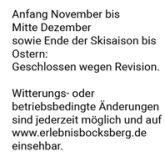

(c) Example of a golden incentive (voucher) (d) Example of a golden incentive (certificate)

Fig. 5 Example of a voucher silver incentive (a) and a certificate silver incentive (b) and example of a voucher golden incentive (c) and a certificate golden incentive (d) 


\section{Appendix 3.2}

Table 6.

Table 6 Overview of the different incentives for the second EcoBus pilot phase

\begin{tabular}{|c|c|c|c|c|}
\hline & \multicolumn{3}{|l|}{ Voucher } & \multirow{2}{*}{$\begin{array}{l}\text { Certificate } \\
\text { Incentive }\end{array}$} \\
\hline & \multicolumn{3}{|l|}{ Incentive } & \\
\hline & GlowGolf & ErlebnisBockBerg & Aloha & Environment \\
\hline & Harz & & Aqualand & Certificate \\
\hline Silver bonus & 3D glasses & Round trip & Two hours sauna & $\begin{array}{c}\text { Information } \\
\text { and confir- } \\
\text { mation on } \\
\text { saved } \mathrm{CO}_{2}\end{array}$ \\
\hline Golden bonus & One free game & Round trip & One day sauna & $\begin{array}{c}\text { Information } \\
\text { and confir- } \\
\text { mation on } \\
\text { saved } \mathrm{CO}_{2}\end{array}$ \\
\hline & (2nd person) & (Gondola lift) + pie + coffee & (2nd person) & \\
\hline Valid until (2019) & 31st December & 31st December & 30th September & Always \\
\hline Limited supply & No & No & 500 & No \\
\hline
\end{tabular}

\section{Appendix 3.3}

Figure 6. 


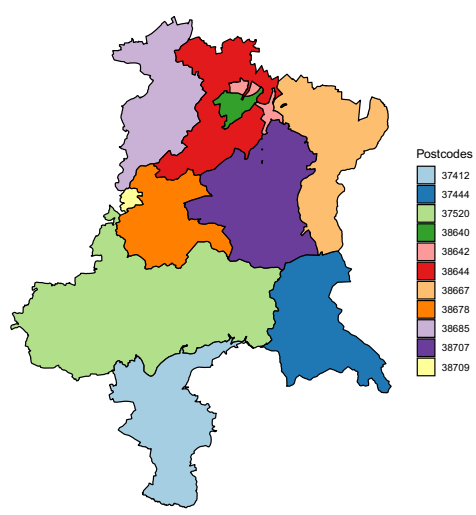

(a) Postcodes of the EcoBus service area

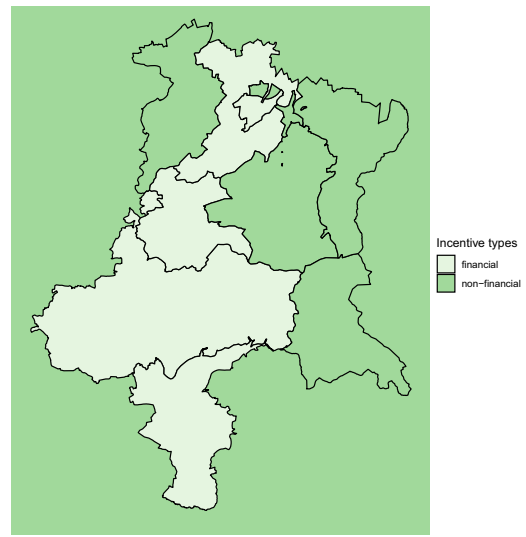

(c) Incentive types of the EcoBus service area (financial=voucher, non-financial $=$ certificate)

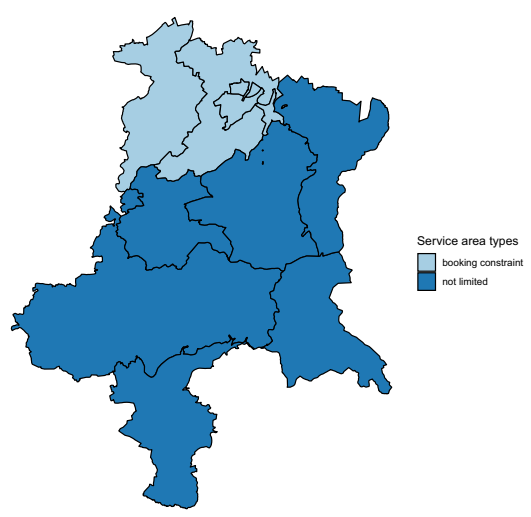

(b) Postcode areas with booking constraint

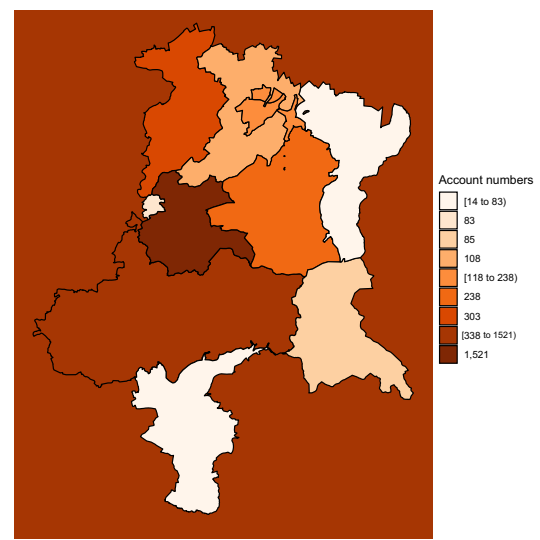

(d) Number of EcoBus accounts (November 2018)

Fig. 6 Overview of the postcodes (a) including the booking constraint (b), the incentive types (c) and number of Ecobus accounts (d). Source: Own representation, postcode shape files: Suche Postleitzahl team 2018

\section{Appendix 4}

The regression models are similar to the models in Section Vouchers vs. Certificates. The second 7 weeks of the pre-treatment phase are pseudo treatments to detect a trend starting before the actual treatment Table 7. 
Table 7 Common trend assumption: Voucher vs. Certificates - Weekly effects
Subset

Dependent variable: weekly EcoBus journeys

(1) (2) (3) (4)

Without Clausthal

\begin{tabular}{|c|c|c|c|c|}
\hline Pseudo treatment $_{1}$ & $\begin{array}{l}-0.035 \\
(0.032)\end{array}$ & $\begin{array}{l}-0.055^{*} \\
(0.028)\end{array}$ & $\begin{array}{l}-0.042 \\
(0.057)\end{array}$ & $\begin{array}{l}-0.110 * * * \\
(0.030)\end{array}$ \\
\hline Pseudo treatment $_{2}$ & $\begin{array}{l}-0.007 \\
(0.066)\end{array}$ & $\begin{array}{l}-0.075 \\
(0.071)\end{array}$ & $\begin{array}{l}-0.102 \\
(0.079)\end{array}$ & $\begin{array}{l}-0.187^{* *} \\
(0.080)\end{array}$ \\
\hline Pseudo treatment $_{3}$ & $\begin{array}{l}0.085 \\
(0.058)\end{array}$ & $\begin{array}{l}0.017 \\
(0.046)\end{array}$ & $\begin{array}{l}-0.033 \\
(0.058)\end{array}$ & $\begin{array}{l}0.079 * \\
(0.043)\end{array}$ \\
\hline Pseudo treatment $_{4}$ & $\begin{array}{l}0.028 \\
(0.076)\end{array}$ & $\begin{array}{l}-0.014 \\
(0.043)\end{array}$ & $\begin{array}{l}-0.046 \\
(0.078)\end{array}$ & $\begin{array}{l}-0.038 \\
(0.058)\end{array}$ \\
\hline Pseudo treatment $_{5}$ & $\begin{array}{l}0.158 * \\
(0.088)\end{array}$ & $\begin{array}{l}0.041 \\
(0.054)\end{array}$ & $\begin{array}{l}0.050 \\
(0.085)\end{array}$ & $\begin{array}{l}-0.010 \\
(0.069)\end{array}$ \\
\hline Pseudo treatment $_{6}$ & $\begin{array}{l}0.097 \\
(0.119)\end{array}$ & $\begin{array}{l}-0.020 \\
(0.092)\end{array}$ & $\begin{array}{l}0.032 \\
(0.168)\end{array}$ & $\begin{array}{l}-0.080 \\
(0.112)\end{array}$ \\
\hline Pseudo treatment $_{7}$ & $\begin{array}{l}0.107 \\
(0.069)\end{array}$ & $\begin{array}{l}-0.018 \\
(0.071)\end{array}$ & $\begin{array}{l}0.034 \\
(0.067)\end{array}$ & $\begin{array}{l}-0.028 \\
(0.091)\end{array}$ \\
\hline Deleted journeys & & $\begin{array}{l}0.037 \\
(0.023)\end{array}$ & & $\begin{array}{l}0.028 \\
(0.020)\end{array}$ \\
\hline Travel time & & $\begin{array}{l}0.063 * * * \\
(0.006)\end{array}$ & & $\begin{array}{l}0.063 * * * \\
(0.012)\end{array}$ \\
\hline Waiting time & & $\begin{array}{l}0.010 * * \\
(0.004)\end{array}$ & & $\begin{array}{l}0.005 \\
(0.003)\end{array}$ \\
\hline $\begin{array}{l}\text { Additional pas- } \\
\text { senger }\end{array}$ & & $\begin{array}{l}0.202 * * * \\
(0.070)\end{array}$ & & $\begin{array}{l}0.211 \\
(0.147)\end{array}$ \\
\hline Active account & & $\begin{array}{l}0.252^{* * * *} \\
(0.016)\end{array}$ & & $\begin{array}{l}0.224 * * * \\
(0.019)\end{array}$ \\
\hline Constant & $\begin{array}{l}0.162 * * * \\
(0.056)\end{array}$ & $\begin{array}{l}-0.015 \\
(0.027)\end{array}$ & $\begin{array}{l}0.178 * * * \\
(0.055)\end{array}$ & $\begin{array}{l}-0.017 \\
(0.028)\end{array}$ \\
\hline Observations & 19,950 & 19,950 & 9,926 & 9,926 \\
\hline $\mathrm{R}^{2}$ & 0.012 & 0.367 & 0.009 & 0.405 \\
\hline Adjusted $\mathrm{R}^{2}$ & 0.011 & 0.367 & 0.007 & 0.404 \\
\hline Residual Std. Error & 1.294 & 1.036 & 1.128 & 0.874 \\
\hline F Statistic & $11.953 * * *$ & $445.180 * * *$ & $4.366^{* * *}$ & $259.687 * * *$ \\
\hline
\end{tabular}

${ }^{*} \mathrm{p}<0.1 ; * * \mathrm{p}<0.05 ; * * * \mathrm{p}<0.01$; Standard errors in parentheses

\section{Appendix 5}

Table 8. 
Table 8 Difference in Differences Model Panel fixed effects (week and account number): Vouchers vs. Certificates - Weekly effects

\begin{tabular}{|c|c|c|c|c|}
\hline \multirow[t]{3}{*}{ Subset } & \multicolumn{4}{|c|}{ Dependent variable: weekly EcoBus journeys } \\
\hline & (1) & (2) & (3) & (4) \\
\hline & & & Without & lausthal \\
\hline \multirow[t]{2}{*}{ Treatment $_{1}$} & $0.194 * *$ & 0.115 & 0.095 & 0.012 \\
\hline & $(0.064)$ & $(0.071)$ & $(0.092)$ & $(0.065)$ \\
\hline \multirow{2}{*}{ Treatment $_{2}$} & 0.123 & 0.039 & -0.002 & -0.015 \\
\hline & $(0.087)$ & $(0.058)$ & $(0.095)$ & $(0.063)$ \\
\hline \multirow{2}{*}{ Treatment $_{3}$} & 0.085 & 0.035 & -0.083 & -0.107 \\
\hline & $(0.091)$ & $(0.077)$ & $(0.101)$ & $(0.076)$ \\
\hline \multirow[t]{2}{*}{ Treatment $_{4}$} & $0.119^{*}$ & 0.076 & -0.023 & -0.064 \\
\hline & $(0.059)$ & $(0.059)$ & $(0.049)$ & $(0.055)$ \\
\hline \multirow[t]{2}{*}{ Treatment $_{5}$} & 0.027 & 0.085 & -0.092 & -0.020 \\
\hline & $(0.093)$ & $(0.081)$ & $(0.088)$ & $(0.085)$ \\
\hline \multirow[t]{2}{*}{ Treatment $_{6}$} & 0.068 & $0.080 * *$ & 0.021 & 0.032 \\
\hline & $(0.038)$ & $(0.028)$ & $(0.075)$ & $(0.043)$ \\
\hline \multirow[t]{2}{*}{ Treatment $_{7}$} & $0.123^{* *}$ & $0.079^{*}$ & 0.136 & $0.099 * *$ \\
\hline & $(0.053)$ & $(0.040)$ & $(0.085)$ & $(0.040)$ \\
\hline \multirow{2}{*}{ treatment $_{8}$} & 0.121 & $0.130^{*}$ & -0.017 & -0.007 \\
\hline & $(0.109)$ & $(0.065)$ & $(0.120)$ & $(0.049)$ \\
\hline \multirow[t]{2}{*}{ Treatment $_{9}$} & 0.122 & 0.125 & 0.054 & 0.017 \\
\hline & $(0.095)$ & $(0.110)$ & $(0.094)$ & $(0.106)$ \\
\hline \multirow[t]{2}{*}{ Treatment $_{10}$} & 0.124 & $0.1587^{*}$ & 0.032 & 0.078 \\
\hline & $(0.126)$ & $(0.087)$ & $(0.129)$ & $(0.099)$ \\
\hline \multirow[t]{2}{*}{ Treatment $_{11}$} & $0.285^{* * *}$ & $0.311 * * *$ & $0.179 * *$ & $0.194 * *$ \\
\hline & $(0.068)$ & $(0.056)$ & $(0.071)$ & $(0.068)$ \\
\hline \multirow[t]{2}{*}{ Treatment $_{12}$} & $0.182 *$ & $0.249 * * *$ & 0.107 & $0.166^{*}$ \\
\hline & $(0.084)$ & $(0.073)$ & $(0.133)$ & $(0.079)$ \\
\hline \multirow[t]{2}{*}{ Treatment $_{13}$} & 0.112 & $0.160^{* *}$ & 0.125 & $0.141 * *$ \\
\hline & $(0.066)$ & $(0.051)$ & $(0.074)$ & $(0.058)$ \\
\hline \multirow[t]{2}{*}{ Treatment $_{14}$} & $0.136^{* *}$ & $0.168 * * *$ & 0.067 & $0.078^{*}$ \\
\hline & $(0.053)$ & $(0.052)$ & $(0.052)$ & $(0.039)$ \\
\hline \multirow[t]{2}{*}{ Deleted journeys } & & $0.019^{*}$ & & 0.012 \\
\hline & & $(0.009)$ & & $(0.008)$ \\
\hline \multirow[t]{2}{*}{ Travel time } & & $0.045^{* * *}$ & & $0.041 * * *$ \\
\hline & & $(0.002)$ & & $(0.004)$ \\
\hline \multirow[t]{2}{*}{ Waiting time } & & $0.010^{* * *}$ & & $0.009^{* * *}$ \\
\hline & & $(0.001)$ & & $(0.001)$ \\
\hline \multirow[t]{2}{*}{ Additional passenger } & & $0.177 * * *$ & & $0.162 * * *$ \\
\hline & & $(0.032)$ & & $(0.044)$ \\
\hline \multirow[t]{2}{*}{ Active account } & & $0.229 * * *$ & & $0.123 * *$ \\
\hline & & $(0.064)$ & & $(0.044)$ \\
\hline Observations & 39,900 & 39,900 & 19,852 & 19,852 \\
\hline Weeks & 28 & 28 & 28 & 28 \\
\hline Accounts & 1425 & 1425 & 709 & 709 \\
\hline $\mathrm{R}^{2}$ & 0.001 & 0.277 & 0.001 & 0.319 \\
\hline Adjusted $\mathrm{R}^{2}$ & -0.037 & 0.249 & -0.038 & 0.292 \\
\hline F Statistic & $2.626 * * *$ & $775.199 * * *$ & 1.306 & $470.833^{* * *}$ \\
\hline
\end{tabular}

$* \mathrm{p}<0.1 ; * * \mathrm{p}<0.05 ; * * * \mathrm{p}<0.01 ;$ Standard errors in parentheses 


\section{Appendix 6}

Figures 7 and 8 .
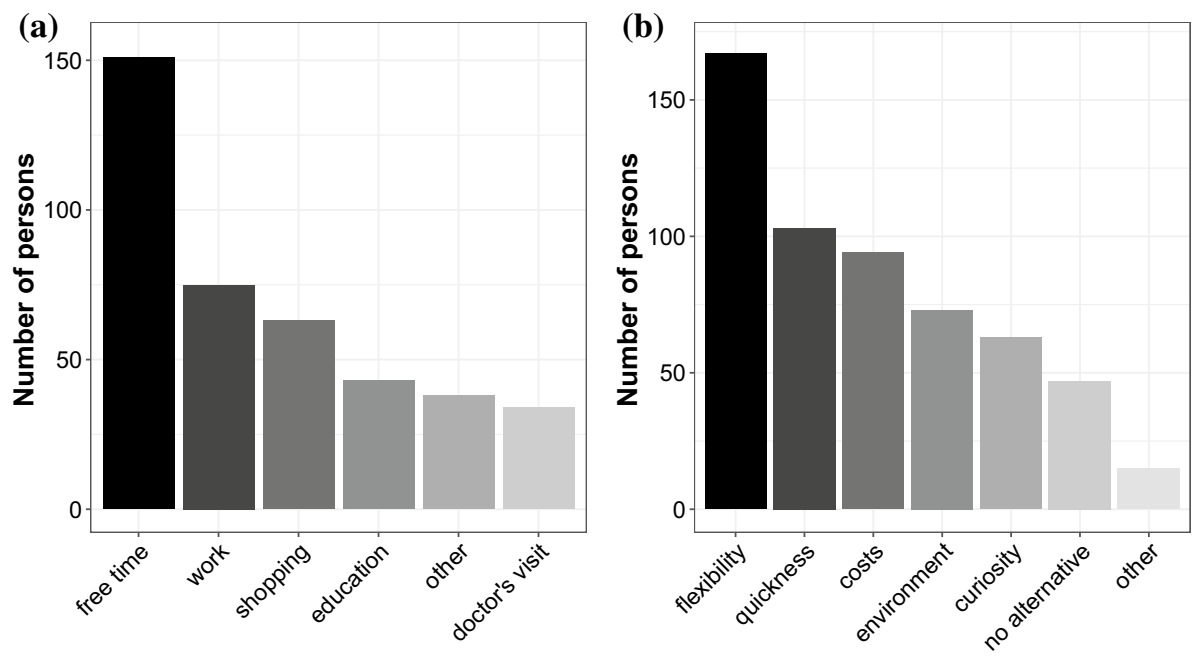

Fig. 7 The purpose (a) and reason (b) using the EcoBus; Observations=194

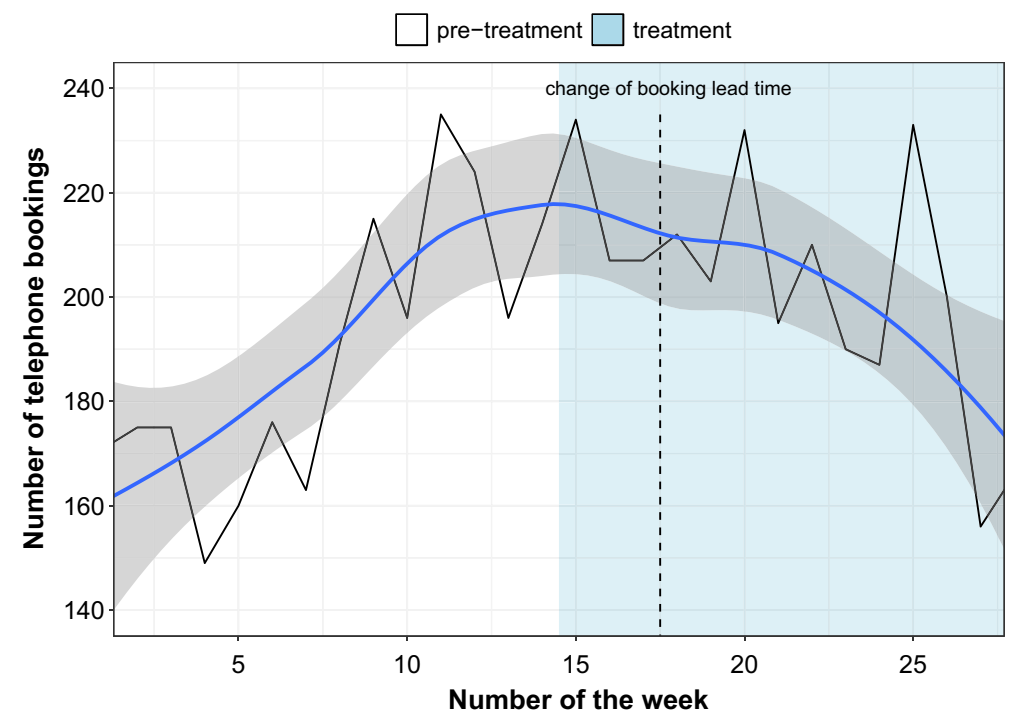

Fig. 8 EcoBus bookings via telephone over time 


\section{References}

Allcott, H., Rogers, T.: The short-run and long-run effects of behavioral interventions: Experimental evidence from energy conservation. Am. Econ. Rev. 104(10), 3003-37 (2014)

Alonso-González, M. J., van Oort, N., Oded, C., Hoogendoorn, S.: Urban Demand Responsive Transport in the Mobility as a Service ecosystem: its role and potential market share, (2017)

Angrist, J.D., Pischke, J.S.: Mostly harmless econometrics: An empiricists companion. Princeton University Press, New Jersy (2008)

Arnott, B., Rehackova, L., Errington, L., Sniehotta, F.F., Roberts, J., Araujo-Soares, V.: Efficacy of behavioural interventions for transport behaviour change: systematic review, meta-analysis and intervention coding. Int. J. Behav. Nutr. Phys. Act. 11(1), 1-23 (2014)

Asensio, O.I., Delmas, M.A.: Nonprice incentives and energy conservation. Proc. Natl. Acad. Sci. 112(6), E510-E515 (2015)

Bamberg, S.: Is a residential relocation a good opportunity to change peoples travel behavior? Results from a theory-driven intervention study. Environ. Behav. 38(6), 820-840 (2006)

Bareket-Bojmel, L., Hochman, G., Ariely, D.: Its (not) all about the Jacksons: Testing different types of short-term bonuses in the field. J. Manage. 43(2), 534-554 (2017)

Baumann, H., Seils, E.: Verfügbare Haushalteinkommen im regionalen Vergleich. (2019). https://www. boeckler.de/pdf/wsi_vm_verfuegbare_einkommen.pdf (last accessed on 2020-06-03)

Bénabou, R., Tirole, J.: Incentives and prosocial behavior. Am. Econ. Rev. 96(5), 1652-1678 (2006)

Berg, J., Ihlström, J.: The importance of public transport for mobility and everyday activities among rural residents. Soc. Sci. 8(2), 58 (2019)

Bowden, H., Hellen, G.: A data driven, segmentation approach to real world travel behaviour change, using incentives and gamification. In Towards User-Centric Transport in Europe (pp. 173-182). Springer, Cham, (2019)

Brake, J., Nelson, J.D., Wright, S.: Demand responsive transport: towards the emergence of a new market segment. J. Transp. Geogr. 12(4), 323-337 (2004)

Charness, G., Gneezy, U.: Incentives to exercise. Econometrica 77(3), 909-931 (2009)

Davison, L., Enoch, M., Ryley, T., Quddus, M., Wang, C.: Identifying potential market niches for Demand Responsive Transport. Res. Transp. Business Manage. 3, 50-61 (2012)

de Kruijf, J., Ettema, D., Kamphuis, C.B., Dijst, M.: Evaluation of an incentive program to stimulate the shift from car commuting to e-cycling in the Netherlands. J. Transport Health 10, 74-83 (2018)

Dolan, P., Metcalfe, R.: Neighbors, knowledge, and nuggets: two natural field experiments on the role of incentives on energy conservation. Becker Friedman Institute for Research in Economics Working Paper, (2589269), (2015)

Durand, A., Harms, L., Hoogendoorn-Lanser, S., Zijlstra, T.: Mobility-as-a-Service and changes in travel preferences and travel behaviour: a literature review. KiMl Netherlands Institute for Transport Policy Analysis, (2018)

EcoBus team (2018). Wohin fährt der EcoBus? https://www.ecobus.jetzt/informationen.html\#wohin-faehrtder-ecobus (last accessed on 2020-06-03)

Enoch, M., Potter, S., Parkhurst, G., Smith, M.: Why do demand responsive transport systems fail?, (2006)

Falk, A.: Gift exchange in the field. Econometrica 75(5), 1501-1511 (2007)

Federal Institute for Research on Building, Urban Affairs and Spatial Development (2017). Raumgliederungen auf Kreisbasis- Kreise und kreisfreie Städte, Kreisregionen. https://www.bbsr.bund.de/BBSR/DE/ Raumbeobachtung/Downloads/downloads_node.html (last accessed on 2020-06-03)

Fujii, S., Gärling, T., Kitamura, R.: Changes in drivers perceptions and use of public transport during a freeway closure: Effects of temporary structural change on cooperation in a real-life social dilemma. Environ. Behav. 33(6), 796-808 (2001)

Fujii, S., Kitamura, R.: What does a one-month free bus ticket do to habitual drivers? An experimental analysis of habit and attitude change. Transportation 30(1), 81-95 (2003)

Gneezy, U., Meier, S., Rey-Biel, P.: When and why incentives (dont) work to modify behavior. J. Econ. Perspect. 25(4), 191-210 (2011)

Graham, J., Koo, M., Wilson, T.D.: Conserving energy by inducing people to drive less. J. Appl. Soc. Psychol. 41(1), 106-118 (2011)

Graham-Rowe, E., Skippon, S., Gardner, B., Abraham, C.: Can we reduce car use and if so, how? A review of available evidence. Transp. Res. Part A: Policy Practice 45(5), 401-418 (2011)

Heyman, J., Ariely, D.: Effort for payment: A tale of two markets. Psychol. Sci. 15(11), 787-793 (2004)

Hunecke, M., Blöbaum, A., Matthies, E., Höger, R.: Responsibility and environment: Ecological norm orientation and external factors in the domain of travel mode choice behavior. Environ. Behav. 33(6), 830-852 (2001) 
Hlavac, M.: stargazer: Well-Formatted Regression and Summary Statistics Tables. R package version 5.2.2. Central European Labour Studies Institute (CELSI). Bratislava, Slovakia. (2018). https://CRAN.Rproject.org/package $=$ stargazer (last accessed on 2020-06-03)

Huang, B., Thomas, T., Groenewolt, B., Claasen, Y., van Berkum, E.: Effectiveness of incentives offered by mobile phone app to encourage cycling: A long-term study. IET Intel. Transport Syst. 15(3), 406-422 (2021)

Hulkkonen, M., Mielonen, T., Prisle, N.L.: The atmospheric impacts of initiatives advancing shifts towards low-emi6ssion mobility: A scoping review. Sci. Total Environ. 713, 136133 (2020)

INKAR (2019). INKAR database. https://www.inkar.de/, Accessed on 9 September 2019

Ito, K., Ida, T., Tanaka, M.: Moral suasion and economic incentives: Field experimental evidence from energy demand. Am. Econ. J. Econ. Pol. 10(1), 240-67 (2018)

Jokinen, J.-P.: Economic Perspectives on Automated Demand Responsive Transportation and Shared Taxi Services-Analytical models and simulations for policy analysis. Aalto University publication series: Doctoral Dissertations 120/2016. PhD thesis. Aalto University. (2016). http://urn.fi/URN:ISBN:978952-60-6870-1 (last accessed on 2020-09-21)

Kosfeld, M., Neckermann, S.: Getting more work for nothing? Symbolic awards and worker performance. Am. Econ. J.: Microecon. 3(3), 86-99 (2011)

Lacetera, N., Macis, M.: Do all material incentives for pro-social activities backfire? The response to cash and non-cash incentives for blood donations. J. Econ. Psychol. 31(4), 738-748 (2010)

Lacetera, N., Macis, M., Slonim, R.: Will there be blood? Incentives and displacement effects in pro-social behavior. Am. Econ. J. Econ. Pol. 4(1), 186-223 (2012)

Lefebvre, M., Stenger, A.: Short- \& long-term effects of monetary and non-monetary incentives to cooperate in public good games: An experiment. PLoS ONE 15(1), e0227360 (2020)

Lechner, M., Rodriguez-Planas, N., Fernández Kranz, D.: Difference-in-difference estimation by FE and OLS when there is panel non-response. J. Appl. Stat. 43(11), 2044-2052 (2016)

Local authority Braunlage (2018). Die Stadt Braunlage in Zahlen, 2018. https://www.stadt-braunlage.com/ 28-stadtinfo/zahlen-und-fakten/19-braunlage-zahlen (last accessed on 2020-06-03)

Local authority Goslar (2017). Einwohner der Gemeinden und Ortsteile. https://www.landkreis-goslar.de/ media/custom/94_4556_1.PDF?1527158415 (last accessed on 2020-06-03)

Local authority Osterode (2012). Ortschaften der Stadt Osterode am Harz. https://www.osterode.de/lebenin-osterode-am-harz/ortschaften/ (last accessed on 2020-06-03)

Local transport authority RBB (n.y.). Harz Übersichtskarte mit RBB Linien. https://www.rbb-bus.de/regio busbs/view/mdb/regiobusbs/pdf/MDB70978-karte_vgharz_201009.pdf (last accessed on 2020-06-03)

Local transport authority VSN (n.y.). Fahrpläne für die Überlandbusse. https://vsninfo.de/de/fahrplaene (last accessed on 2020-06-03)

Máca, V., Ščasný, M., Zvěřinová, I., Jakob, M., Hrnčrîr, J.: Incentivizing commuter cycling by financial and non-financial rewards. Int. J. Environ. Res. Public Health 17(17), 6033 (2020)

Maréchal, M.A., Thöni, C.: Hidden persuaders: do small gifts lubricate business negotiations? Management Science (2018)

Masclet, D., Noussair, C., Tucker, S., Villeval, M.C.: Monetary and nonmonetary punishment in the voluntary contributions mechanism. Am. Econ. Rev. 93(1), 366-380 (2003)

Nyga, A., Minnich, A., Schlüter, J.: The effects of susceptibility, eco-friendliness and dependence on the Consumers Willingness to Pay for a door-to-door DRT system. Transp. Res. Part A: Policy Practice 132, 540-558 (2020)

Percy, J.: Die Metallurgie : Gewinnung und Verarbeitung der Metalle und ihrer Legirungen, in praktischer und theoretischer, besonders chemischer Beziehung. Vieweg. (1872)

Pütz, T., Schönfelder, S.: Verkehrsbild Deutschland: Angebotsqualitäten und Erreichbarkeiten im öffentlichen Verkehr. Bundesinstitut für Bau-, Stadt- und Raumforschung (BBSR) im Bundesamt für Bauwesen und Raumordnung (BBR). Verkehrsbild Deutschland - Angebotsqualitäten und Erreichbarkeiten im öffentlichen Verkehr, 2018,8, (2018)

R Core Team (2019). R: A Language and Environment for Statistical Computing. R Foundation for Statistical Computing. Vienna, Austria. https://www.R-project.org (last accessed on 2020-06-03)

Santi, P., Resta, G., Szell, M., Sobolevsky, S., Strogatz, S.H., Ratti, C.: Quantifying the benefits of vehicle pooling with shareability networks. Proc. Natl. Acad. Sci. 111(37), 13290-13294 (2014)

Sörensen, L., Bossert, A., Jokinen, J.P., Schlüter, J.: How much flexibility does rural public transport need?Implications from a fully flexible DRT system. Transp. Policy 100, 5-20 (2021)

State Office for Statistics Lower Saxony (2019a). 12412 - Bevölkerungsvorausberechnungen. https://www1. nls.niedersachsen.de/statistik/html/default.asp (last accessed on 2020-06-03) 
State Office for Statistics Lower Saxony (2019b). 45412 - Betriebe; Ankünfte; Übernachtungen; Aufenthaltsdauer; Schlafgelegenheitenauslastung nach Betriebsart (Reisegebiet) . https://www1.nls.niedersachsen. $\mathrm{de} / \mathrm{statistik} / \mathrm{html} / \mathrm{default}$ asp (last accessed on 2020-06-03)

Suche Postleitzahl team (2018). Grenzen als Shapefile. https://www.suche-postleitzahl.org/downloads (last accessed on 2020-06-03)

Thøgersen, J., Møller, B.: Breaking car use habits: The effectiveness of a free one-month travelcard. Transportation 35(3), 329-345 (2008)

Tsirimpa, A., Polydoropoulou, A., Pagoni, I., Tsouros, I.: A reward-based instrument for promoting multimodality. Transp. Res. Part F: Traffic Psychol Behav 65, 121-140 (2019)

Wickham, H.: ggplot2: Elegant Graphics for Data Analysis. Springer-Verlag New York. (2016). https:// ggplot2.tidyverse.org (last accessed on 2020-06-03)

Publisher's Note Springer Nature remains neutral with regard to jurisdictional claims in published maps and institutional affiliations.

Aljoscha Minnich is a PhD student at the University of Hamburg. The doctoral project relates to climate change research. He is interested in the fields of experimental, behavioural and environmental economics. His research interests also include transport research and quasi-experimental evaluations.

Holger A. Rau is an Assistant Professor at the University Göttingen. His research interests are experimental and behavioral economics, social preferences, gender differences, and behavioral finance. He especially focuses on laboratory and field approaches to analyze the functioning of work incentives and their impact on labor-market phenomena such as the gender wage gap. He is also interested in the behavioral effects of field interventions.

Jan Christian Schlüter is an Independent Research Group Leader and Head of the Econophysics Lab at the Technical University of Dresden. Before that, he was a Group Leader at the Max Planck Institute for Dynamics and Self-Organization, where he carried out the EcoBus project in a leading position. His research interests are flexible transport systems, complex urban dynamics and econophysics. He especially focuses on field experiements and simulations to analyze human behavior in the field of transport and energy. 